\title{
Geological and structural setting of the Vinodol Valley (NW Adriatic, Croatia): insights into its tectonic evolution based on structural investigations
}

\author{
Damir Palenik ${ }^{1 *}$, Dubravko Matičec ${ }^{1}$, Ladislav Fuček ${ }^{1}$, Bojan Matoš ${ }^{2}$, Marijan Herak ${ }^{3}$ \\ and Igor Vlahović ${ }^{2}$ \\ ${ }^{1}$ Croatian Geological Survey, Department of Geology, Sachsova 2, HR-10000 Zagreb, Croatia; ( ${ }^{*}$ corresponding author: dpalenik@hgi-cgs.hr) \\ ${ }^{2}$ University of Zagreb, Faculty of Mining, Geology and Petroleum Engineering, Department of Geology and Geological Engineering, Pierottijeva 6 \\ HR-10000 Zagreb, Croatia \\ ${ }^{3}$ University of Zagreb, Faculty of Science, Department of Geophysics, Horvatovac 95, HR-10000 Zagreb, Croatia
}

doi: $10.4154 / g c .2019 .13$

Article history:

Manuscript received January 28, 2019 Revised manuscript accepted May 31, 2019 Available online October 31, 2019

\begin{abstract}
The area of the Vinodol Valley and Bakar Bay represents a NW-SE oriented valley in the NW Adriatic characterised by prominent historical and instrumentally recorded seismicity. As part of the greater geodynamic domain including the Ilirska Bistrica-Rijeka-Senj seismogenic fault zone, new geological and structural data addressing the tectonic evolution of the area were collected in order to better understand the focal mechanisms of previous earthquakes and to enable identification of potential seismogenic sources.

Mapped informal lithostratigraphic units mostly correspond to the Upper Cretaceous, Palaeogene and Quaternary successions described in other parts of the External Dinarides. However, a shorter stratigraphic range of the Gornji Humac fm., the youngest Cretaceous unit in the study area, was determined and suggests that the uplifted area in the central NW part of the Adriatic Carbonate Platform already comprised several thousand $\mathrm{km}^{2}$ (from W and NW Istria to Krk and Vinodol area) at the end of the Turonian.

Structural measurements of the fault planes in the study area generally correspond to the existing structural model of the tectonic evolution of the Dinarides. However, in contrast to the SW vergences typical of the Dinarides, NE-vergent reverse structures are common, especially along the SW margin of the Vinodol Valley. Cross-cutting relationships suggest that transpressional (NW-SE and NE-SW striking dextral and sinistral faults) and extensional features (NW-SE and NE-SW striking normal faults) are structurally concurrent or younger than the reverse faults, suggesting a change in the palaeostress field during the Neogene-Quaternary, with prevalent transpression and radial extension. Comparison of results of the palaeostress field analysis and the constructed synthetic focal mechanisms on one side, with available focal mechanism solutions for earthquakes within the llirska Bistrica-Rijeka-Senj seismogenic fault zone on the other, shows a favourable orientation of the observed NW-SE and NE-SW striking faults with respect to the recent compressional/transpressional stress field ( $\mathrm{N}-\mathrm{S}$ oriented $\mathrm{P}$-axis), indicating these as potential seismogenic sources within the study area.
\end{abstract}

Keywords: NW Adriatic, Vinodol Valley, Bakar Bay, SW and NE vergences compression/transpression, neotectonic activity, focal mechanism solutions, seismicity

\section{INTRODUCTION}

The Vinodol Valley is a $20 \mathrm{~km}$ long NW-SE oriented valley which runs parallel to the NE Adriatic coastline, stretching from Križišce in the NW to Novi Vinodolski in the SE. The area of the Bakar Bay represents its geomorphological and geological extension towards the NW (Fig. 1).

The most important geological investigation of the wider area of the Vinodol Valley and Bakar Bay was undertaken for the Basic Geological Map of SFRY at a 1:100,000 scale (ŠUŠNJAR et al., 1970). Accompanying explanatory notes (GRIMANI et al., 1973) also include a review of previous studies. In addition to these geological investigations associated with the Basic Geological Map and its explanatory notes, the most important geological and structural studies of the Vinodol Valley were those by BLAŠKOVIĆ $(1991,1997,1998,1999,2005)$, in which he proposed a tectonic concept of the Vinodol Valley area.

The area of the Vinodol Valley and Bakar Bay was investigated as a seismotectonically active area by PRELOGOVIĆ et al. (1981, 1982, 1995), HERAK et al. (1996, 2017), MARKUŠIĆ \&
HERAK (1999), HERAK \& HERAK (2017), and IVANČIĆ et al. (2018). These authors reported data on instrumental and historical seismic activity in the area and discussed the potential seismic sources.

Research presented here was performed in the framework of two ongoing scientific projects funded by the Croatian Science Foundation (HRZZ): VELEBIT (Grant no. IP-2014-09-9666) and GEOSEKVA (Grant no. IP-2016-06-1854). The VELEBIT project represents a multidisciplinary research approach addressing correlation of seismological data and tectonic framework in the neighbouring Velebit Mt. region, which is characterised by low seismicity and weak to moderate magnitude $(\mathrm{M} \leq 5)$ earthquakes at shallow depths. The main research objectives of the GEOSEKVA project are the production of new geological maps (at 1:25,000 and 1:50,000 scales) and 3D geological models of selected structures in the wider Kvarner region, as well as the broadening of the seismic station network and construction of a relevant seismotectonic model of the Kvarner region. 


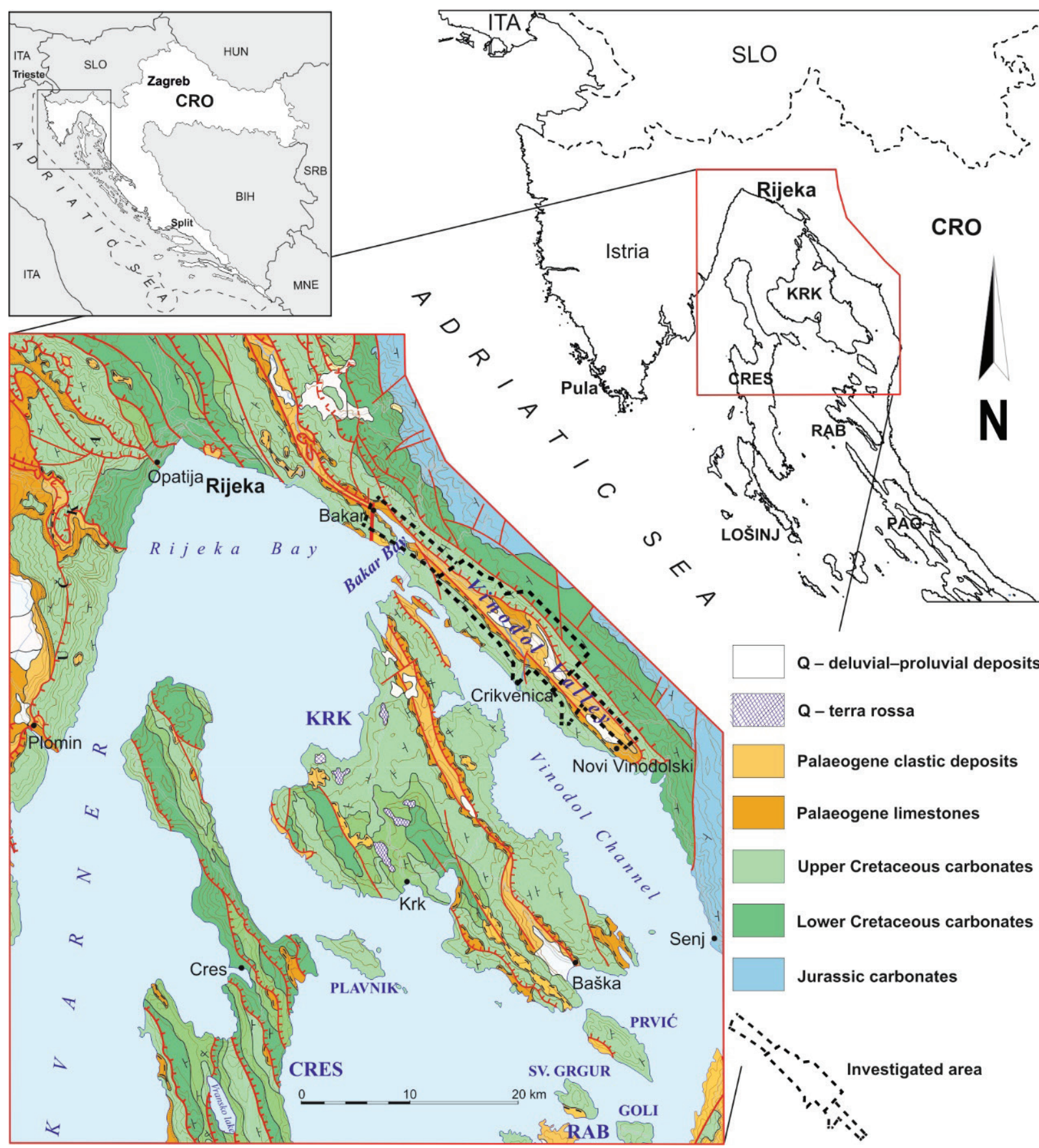

Figure 1. Location map and schematic geological map of the investigated and wider areas of the Vinodol Valley and Bakar Bay. Modified from the Basic Geological Map of the Republic of Croatia 1:300,000 (HGl, 2009).

The main focus of the research in the Vinodol Valley was the geological mapping from Križišće in the NW to Kričina in the SE accompanied by detailed structural-geological research of the Vinodol Valley and Bakar Bay (its continuation towards the NW). Such investigation, together with new data on the focal mechanisms of previous earthquakes could contribute to greater understanding of the tectonic evolution of the study area, including fault kinematics and identification of potential seismogenic structures.

\section{METHODOLOGY}

\subsection{Geological mapping of the study area}

The first phase of the research was focused on production of the new geological map of the Vinodol Valley and its border areas based on lithostratigraphic principles. The central part of the Vinodol Valley has been mapped at 1:5,000 scale, while the marginal parts were mapped at 1:25,000 scale.

Due to the intense tectonics, thicknesses of individual lithostratigraphic units were estimated from geological cross-sections and compared with contemporaneous lithostratigraphic units from neighbouring areas.

\subsection{Structural-geological investigation and analysis}

Structural measurements were performed along the SW and NE edges of the Vinodol Valley as well as in the Bakar Bay.

Within an approximately $30 \mathrm{~km}$ long and $1-5.5 \mathrm{~km}$ wide area, structural data on outcrop-scale fault slips were collected. During analysis, for determination of fault kinematics in relation 
to the past and present stress fields, we used data of field measurements of dip direction and dip angle of fault planes and orientation of carbonate slickensides defined by azimuth and plunge, and, wherever possible, their sense of movement. Despite the relatively weathered outcrops and steep terrain, more than 120 sets of shear joint/fault planes data were gathered at 127 stations along the NE and SW margins of the Vinodol Valley and Bakar Bay. In some places, overlapping and crosscutting relationships between the observed striations enabled the relative temporal comparison of deformation. Based on kinematic criteria, the structural data were separated into compatible datasets and processed by Tectonics FP software (ORTNER et al., 2002). Using the P-T axis method (TURNER, 1953; MARRETT \& ALLMENDINGER, 1990) theoretical maximum $\left(\sigma_{1}\right)$, intermediate $\left(\sigma_{2}\right)$ and minimum stress axes $\left(\sigma_{3}\right)$ were calculated, whereas using the computed Right Dihedra Method (ANGELIER \& MECHLER, 1977) synthetic focal mechanisms for the analysed fault segments were determined, i.e., palaeo-synthetic focal mechanisms as representations of the palaeostress fields.

\section{RESULTS}

\subsection{Geological mapping of the Vinodol Valley}

Geological mapping determined that both margins of the Vinodol Valley are in general fault-bounded, whereas earlier proposals suggested that only the NE margin was fault bounded (ŠUŠNJAR et al., 1970). Along the NE edge of the Vinodol Valley reverse faults are characterised by tectonic transport to the SW, while those along the SW edge of the Vinodol Valley mostly indicate the opposite direction of tectonic transport, towards the NE, which is, although quite rare in the Dinarides, very common in the structures of the neighbouring Velebit Mt. and Krk island (VLAHOVIC et al., 2012; ŚRODOŃ et al., 2018; TOMLJENOVIĆ et al., 2018). In addition to a completely new detailed lithostratigraphic subdivision of deposits, this is one of the key improvements in respect to the previous geological map of the area (ŠUŠNJAR et al., 1970).

On the basis of the geological map (Fig. 2) five transverse geological cross-sections of the Vinodol Valley have been constructed (Fig. 3).

\subsection{Lithostratigraphic units of the Vinodol Valley}

Previous geological maps were based on the chronostratigraphic approach (ŠUŠNJAR et al., 1970; BLAŠKOVIĆ, 1999), so the map presented here is the first one based on lithostratigraphic principles. Upper Cretaceous lithostratigraphic units were named after, and compared to, the informal lithostratigraphic units already defined in other areas of the External Dinarides (GUŠIĆ \& JELASKA, 1990). A total of three Upper Cretaceous, three Palaeogene and four Quaternary units have been described in the study area.

\subsubsection{Upper Cretaceous}

The oldest informal lithostratigraphic unit of the Vinodol Valley is the Cenomanian Milna fm., corresponding to the succession at the locus typicus - the island of Brač (GUŠIĆ \& JELASKA, 1990). It is composed of well-bedded limestones of a light brown-

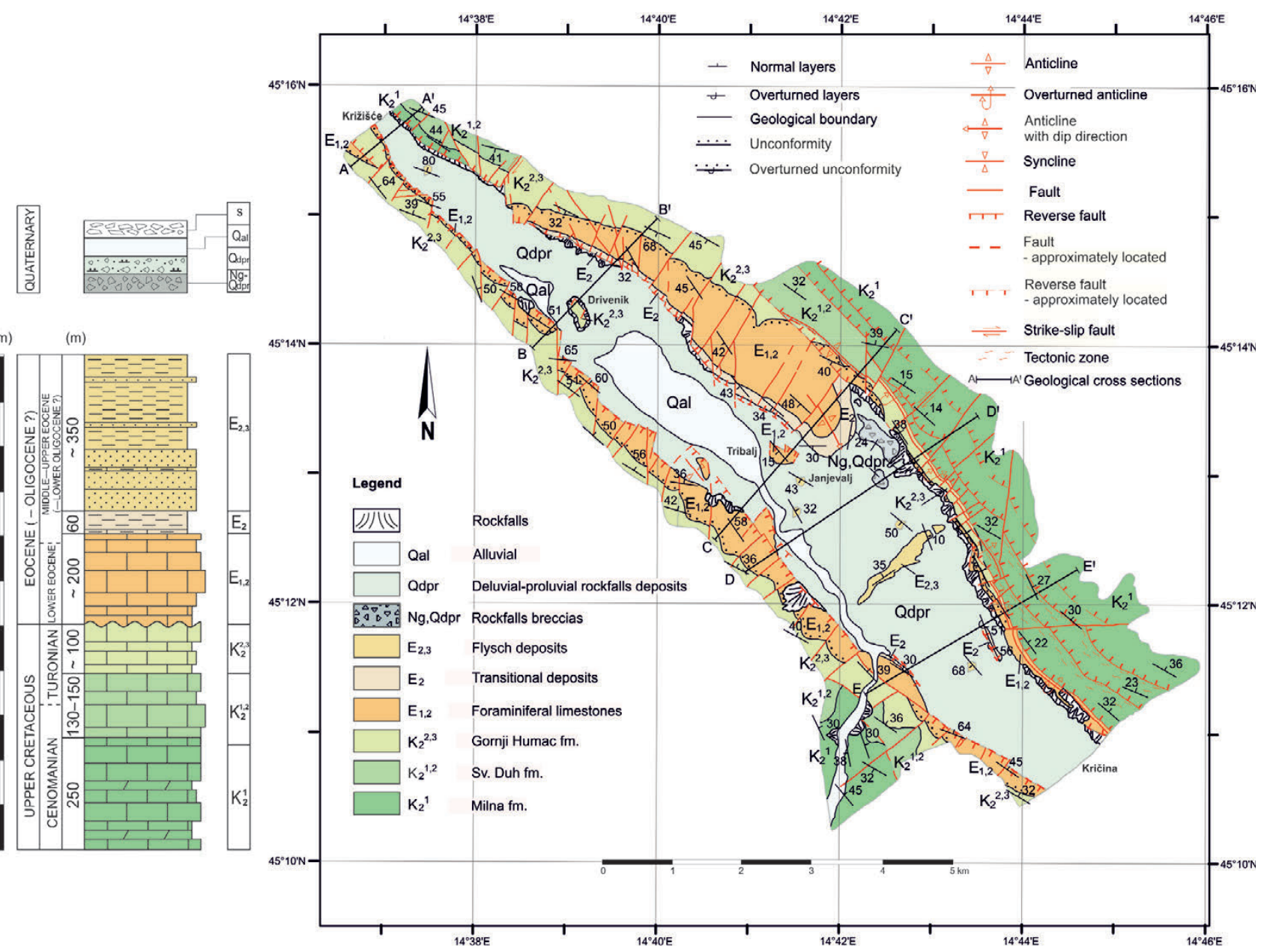

Figure 2. Geological map and schematic geological column of the Vinodol Valley from Križišće to Kričina. 

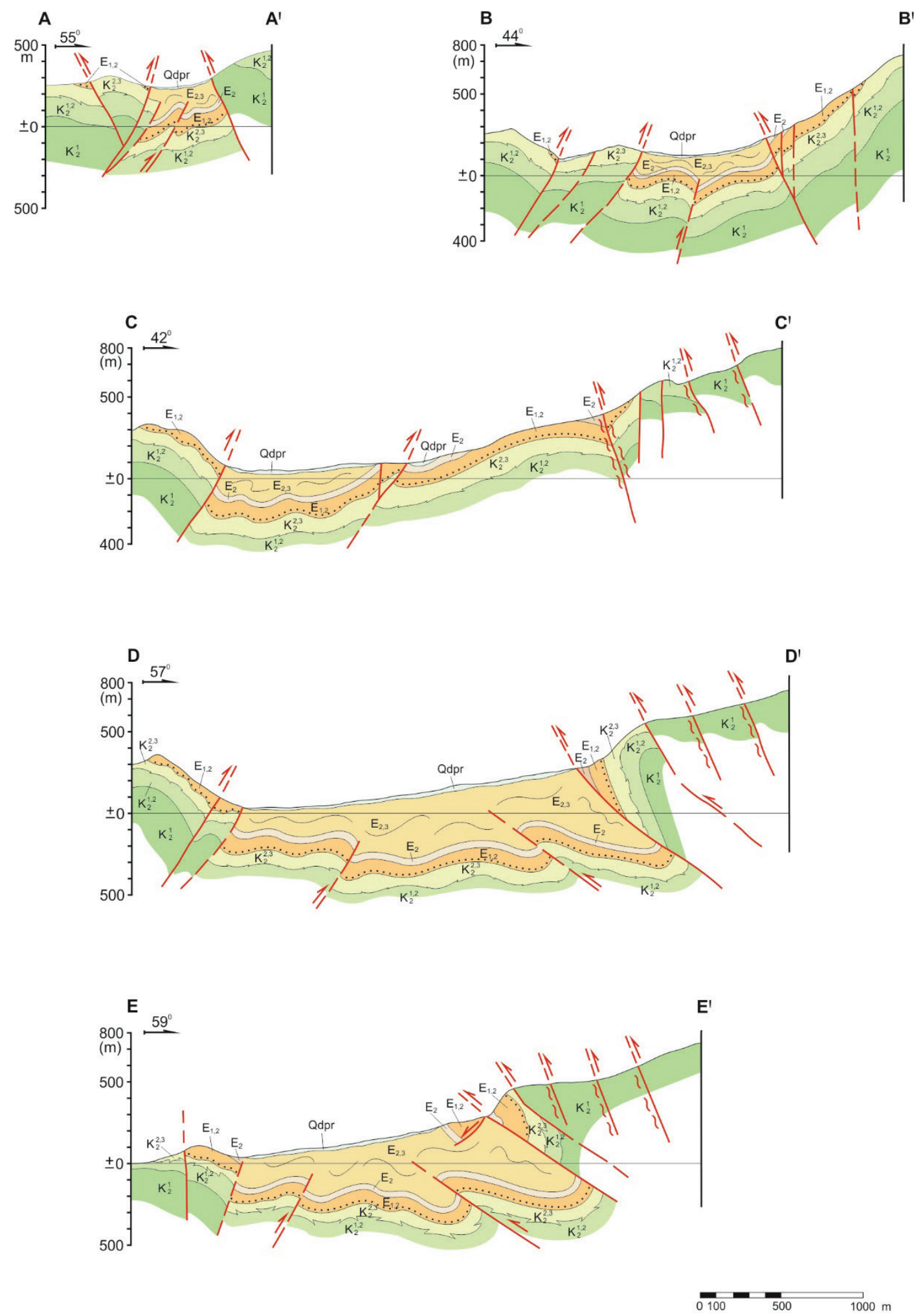

Figure 3. Transverse geological cross-sections of the Vinodol Valley.

grey colour composed of mudstones to wackestones and peloidbioclastic packstones and grainstones with variable amounts of radiolitid rudist debris and rare ostreid shells. Rudist floatstones and/or rudstones are relatively rare, as are layers containing chondrodonts and LLH stromatolites, indicating deposition in shallow subtidal to peritidal environments. The microfossil assemblage includes the benthic foraminifera Chrysalidina gradata d'ORBIGNY, Nummuloculina regularis PHILIPPSON, Broeckina (P.) balcanica CHERCHI et al., Pseudolithuonella reicheli
MARIE and alveolinids, indicating a Middle to Upper Cenomanian age. Macrofossils are relatively rare, represented by indeterminate radiolitid rudists and chondrodont shells. The thickness of the Milna fm. may be estimated at c. $250 \mathrm{~m}$ (not including the lower part of the unit which does not crop out in the study area).

Global relative sea-level rise during the Late CenomanianEarly Turonian (HAQ et al., 1987; HARDENBOL et al., 1998) was also characterised by the widespread Oceanic Anoxic Event 2 
(OAE2; SCHLANGER \& JENKYNS, 1976) which, in the area of the Adriatic Carbonate Platform, is recognized as an informal lithostratigraphic unit - the Sv. Duh fm. (GUŠIĆ \& JELASKA, 1990). In the studied area the unit is composed of thick-bedded light brownish mudstones and mudstone-wackestones. Besides a variable, but significant amount of pithonelomorphic calcispheres (Pithonella ovalis (KAUFMANN), Pithonella sphaerica (BONET) and Pithonella innominata (BONET)) rocks of this unit contain rare indeterminate planktonic foraminifera, and in the lower and upper part shallow-marine ostracods and miliolids as well as bioclasts of gastropods and bivalves. The Sv. Duh fm. was deposited within temporary drowned platform environments, and transitions from the underlying and to the overlying shallow-marine deposits are gradual. Based on the superposition, microfossil assemblage and similar deposits in neighbouring Istria (VLAHOVIĆ et al., 2002) stratigraphic age of Sv. Duh fm. may be estimated as Upper Cenomanian to Lower Turonian. Due to intense post-sedimentary tectonics in the study area thickness of deposits cannot be measured directly, but may be approximated at 130-150 m.

The Gornji Humac fm. (first established on the island of Brač by GUŠIĆ \& JELASKA, 1990) represents the youngest Cretaceous deposits in the study area, cropping out along the slopes of the Vinodol Valley and representing the footwall of the transgressive Palaeogene Foraminiferal limestones. It is composed of fenestral mudstones, mudstone-wackestones with benthic foraminifera, calcareous algae, ostracods, small bioclasts and peloids, packstones with peloids and benthic foraminifera and relatively rare rudist floatstones. They were deposited in re-established peritidal environments and in places contain numerous Decastronema (Aeolisaccus) kotori (RADOIČIĆ) and Thaumatoporella parvovesiculifera (RAINERI), microfossils typical for this unit over the entire Adriatic Carbonate Platform area. Findings of the benthic foraminifera Pseudocyclammina sphaeroidea GENDROT indicates an Upper Turonian age for the deposits of this lithostratigraphic unit. In the study area, the uppermost part of the Gornji Humac fm. deposits is very karstified, more or less intensely recrystallized and coloured yellowish to reddish due to a very long stratigraphic hiatus (its duration may be estimated at c. 35-40 My). Therefore, the total thickness of the Gornji Humac fm. varies laterally from c. 70 to around $100 \mathrm{~m}$.

\subsubsection{The Palaeogene}

Eocene Foraminiferal limestones crop out along the slopes of the Vinodol Valley, transgressively overlying the Upper Cretaceous deposits of the Gornji Humac fm. This unit is characterised by significant lateral and vertical facies diversity, probably caused by variable palaeorelief resulting in the mixing of organisms from different environments. Therefore, although a general deepeningupward trend is recognizable, Foraminiferal limestones in the study area cannot be separated into sub-units usually named after predominant benthic foraminifera (from older and shallower to younger and deeper facies zones the usual sequence is from Miliolid, through Alveolinid and Nummulitid to Orthophragmid bearing limestones). These limestones are mostly represented by wackestones and/or packestones with variable amounts of foraminifera tests and other bioclasts. Younger part of the deposits are characterised by the predominance of orthophragmids containing glauconite and a few other non-carbonate bioclasts. The estimated thickness of Foraminiferal limestones in the study area is c. $200 \mathrm{~m}$, and they are of Lower-Middle Eocene age.

Transitional deposits are a succession of blueish to grey marlstones with 20-30 cm clayey limestone intercalations, rep- resenting a gradual deepening, i.e. transition from shallow-marine Foraminiferal limestones to deep-marine Flysch deposits. They are most clearly visible along the NE margin and in the SE part of the Vinodol Valley. This unit is characterised by glauconite grains, both detrital and diagenetic in origin. In the lower part, sea urchins are common in some beds, while the upper part of the unit often contains irregular chert nodules. The estimated thickness of the Transitional deposits in the study area is about $60 \mathrm{~m}$, and based on superpositional relationships they are probably of Middle Eocene age.

Flysch deposits are represented by the alternation of medium-sized, well-sorted carbonate/quartz/mica sandstones commonly showing normal gradation and grey-blue marls. However, sandstones are not regularly distributed since they are much more common in the NW part of the Vinodol Valley while in its SE part marls predominate. The Flysch deposits are usually considered to be of the Middle to Upper Eocene age (GRIMANI et al., 1973), although some studies in neighbouring areas indicate a possibly younger age (ŠPARICA et al., 2005; MIKES et al., 2008). Although the Flysch deposits are mostly covered by Quaternary deposits their thickness in the study area probably does not exceed $350 \mathrm{~m}$, as estimated from geological profiles.

\subsubsection{Quaternary}

Rockfall breccias cover marginal areas of the Vinodol Valley and are characterised by a variable but generally high degree of lithification by carbonate cements. They consist mainly of unsorted limestone debris of typically variable stratigraphic ages, although some breccias contain clasts of only one lithostratigraphic unit, depending on their source area. The stratigraphic age of some completely lithified breccias may be probably even older than the Quaternary.

Deluvial-proluvial deposits are represented by chaotic masses of angular to slightly rounded, unsorted limestone fragments ranging in size from mm- to metre-sized blocks within a mostly reddish clayey matrix derived mostly from the Mediterranean red soil (terra rossa).

Alluvial deposits - river and stream beds of the Vinodol Valley are often filled with gravels characterised by variable degrees of roundness and different fragment sizes. The material for these deposits mainly originates from the carbonate hinterland (Cretaceous and Palaeogene limestones) and partly from the sandstone horizons within the Flysch deposits. Flood plains are characterised by the deposition of fine-grained sands, silty mud and clay.

Rockfall deposits - active, unlithified rockfall deposits in the form of talus are located along the steep margins of the Vinodol Valley. They are more frequent and of larger dimensions along the NE valley margins. Their fragments are angular and of different sizes, being the result of erosion of the steep carbonate cliffs of the Vinodol Valley and its immediate hinterland.

\subsection{Structural data analysis results within the Vinodol fault zone}

Within the structural field investigations in the study area, along the NE and SW margins of the Vinodol Valley and Bakar Bay, i.e. the Vinodol fault zone (VFZ; Fig. 4) more than 120 shear joint/ fault plane data on 127 geological stations have been collected (Fig. 4). According to the structural measurements, the area of the VFZ can be subdivided into the NE Vinodol Fault Zone (NEVFZ) and the SW Vinodol Fault Zone (SWVFZ) (Fig. 4). Faults are characterised by both dip-slip and strike-slip kinematics, as well as oblique-slip kinematics characterised by a predom- 


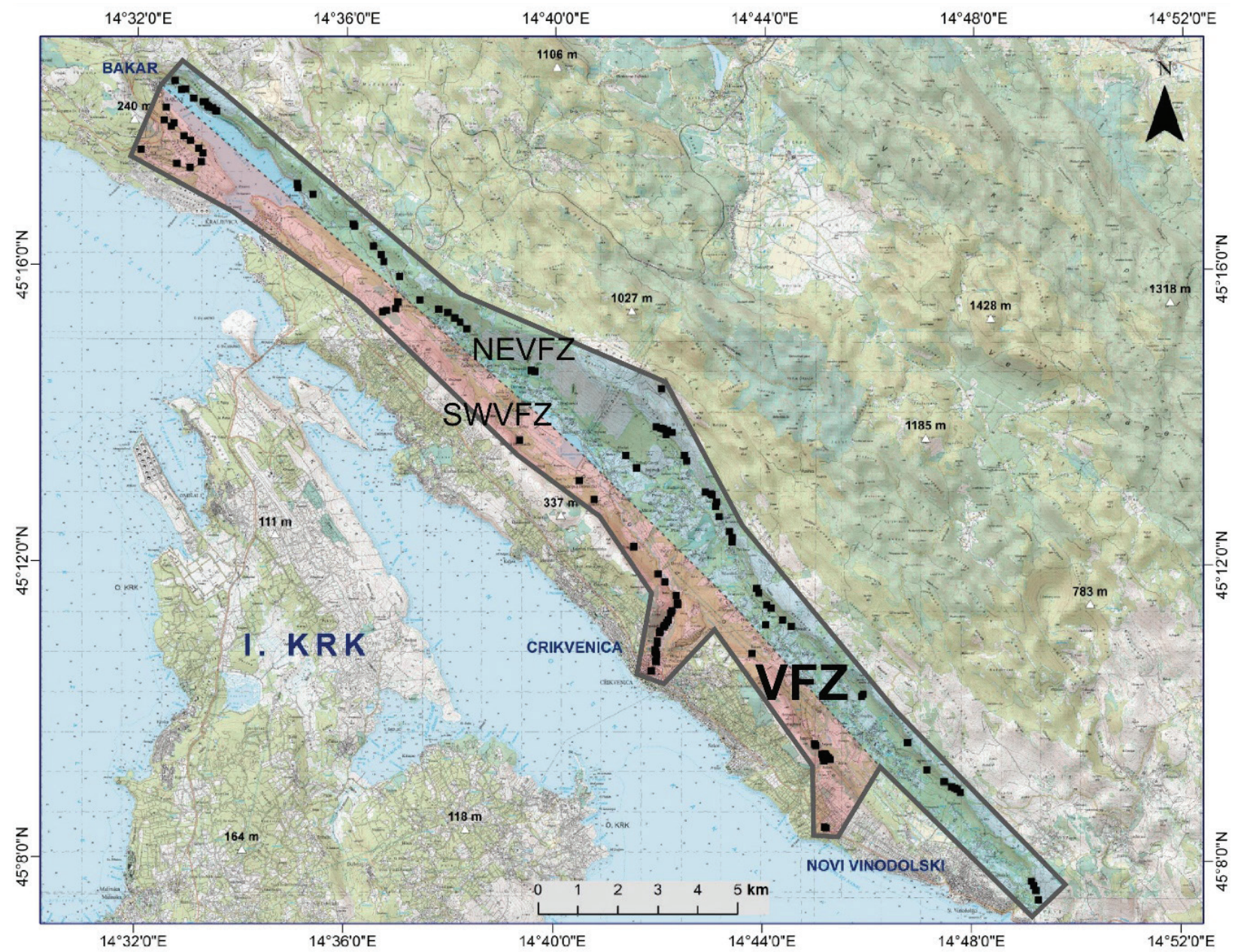

Figure 4. Topographic map of the Vinodol Valley and Bakar Bay, i.e. the Vinodol fault zone (VFZ) with 127 locations of structural measurements. The VFZ is subdivided into the NE Vinodol Fault Zone (NEVFZ), which is coloured with a blueish polygon, and the SW Vinodol Fault Zone (SWVFZ) coloured with a reddish polygon.

inant dip-slip reverse component. In the NE Vinodol (NEVFZ) and SW Vinodol (SWVFZ) fault zones (Fig. 4) kinematic criteria were used to separate the collected structural data into compatible structural datasets.

Within the Vinodol fault zone, along the NE and SW margins of the Vinodol Valley and Bakar Bay (NEVFZ and SWVFZ; Fig. 4), 48 and 72 fault planes were measured in the Upper Cretaceous and Palaeogene carbonate rocks, respectively. Those fault planes show predominant NW-SE and NE-SW strike directions. With respect to the fault kinematics, data collected along the NEVFZ show 19 fault planes with strike-slip kinematics and 29 fault planes with dip-slip kinematics, out of which 8 have normal and 21 exhibit reverse kinematics. Field structural measurements in the SWVFZ area encompassed 36 observed fault planes with strike-slip kinematics and 36 fault planes with dip-slip kinematics, i.e. 18 normal and 18 reverse kinematics. Taking into account the kinematic criteria, the three aforementioned main categories were subdivided into compatible fault groups and fault group subsets (Fig. 5).

Results of structural analysis in the VFZ, i.e. NEVFZ and SWVFZ show that observed reverse fault planes can be separated into three fault groups and six group subsets (Fig. 5 and Table 1). The first group of observed reverse faults (VFZ/RF1) comprise data of similar fault kinematics measured both along the NE and SW margins of the VFZ. In general it is characterised by two fault group subsets i.e. conjugate fault pairs characterised by the NW-
SE strike, dipping both towards the NE and SW (dip angle c. $60^{\circ}$ ) (Table 1). The first subset with an average NE dip direction and SW-directed tectonic transport (Figs. 5-7) indicates thrusting of the Upper Cretaceous deposits and Palaeogene Foraminiferal limestones over younger Palaeogene clastic deposits. It was predominanty observed in the NW and central parts of the NEVFZ (Fig. 3; see structural diagrams for the VFZ/RF1 group in the Fig. 5 and Table 1 for details). The second subset of fault planes is characterised by an average SW dip direction and NE-directed tectonic transport and was measured within the main thrusting fault zone along the SW margin of the Vinodol Valley, generally indicating NE tectonic transport (see cross-sections in the Fig. 3, structural diagrams for the group VFZ/RF1 in the Fig. 5 and Table 1). In the SE part and along the NE margin of the Vinodol Valley, older Upper Cretaceous deposits (the Milna fm.) are thrust over the Palaeogene Foraminiferal limestones and clastic rocks, whereas along the SW margin of the Vinodol Valley Palaeogene Foraminiferal limestones are thrust over the Eocene Flysch deposits (see Figs. 3 and 8). The slight bending of the NEVFZ in its central part (in the vicinity of Tribalj; Figs. 2 and 3) implies also a slight change of the fault's strike and slickenside orientation, which suggests the transition from pure reverse dip-slip motion to locally reverse, dextral/ sinistral oblique-slip motions (see fault planes with SW-dipping directions on group NE/RF1 diagram in the Fig. 5).

Structural analysis of the representative palaeostress field using the P-T axis method (TURNER, 1953; MARRETT \& 


\section{VINODOL FAULT ZONE}
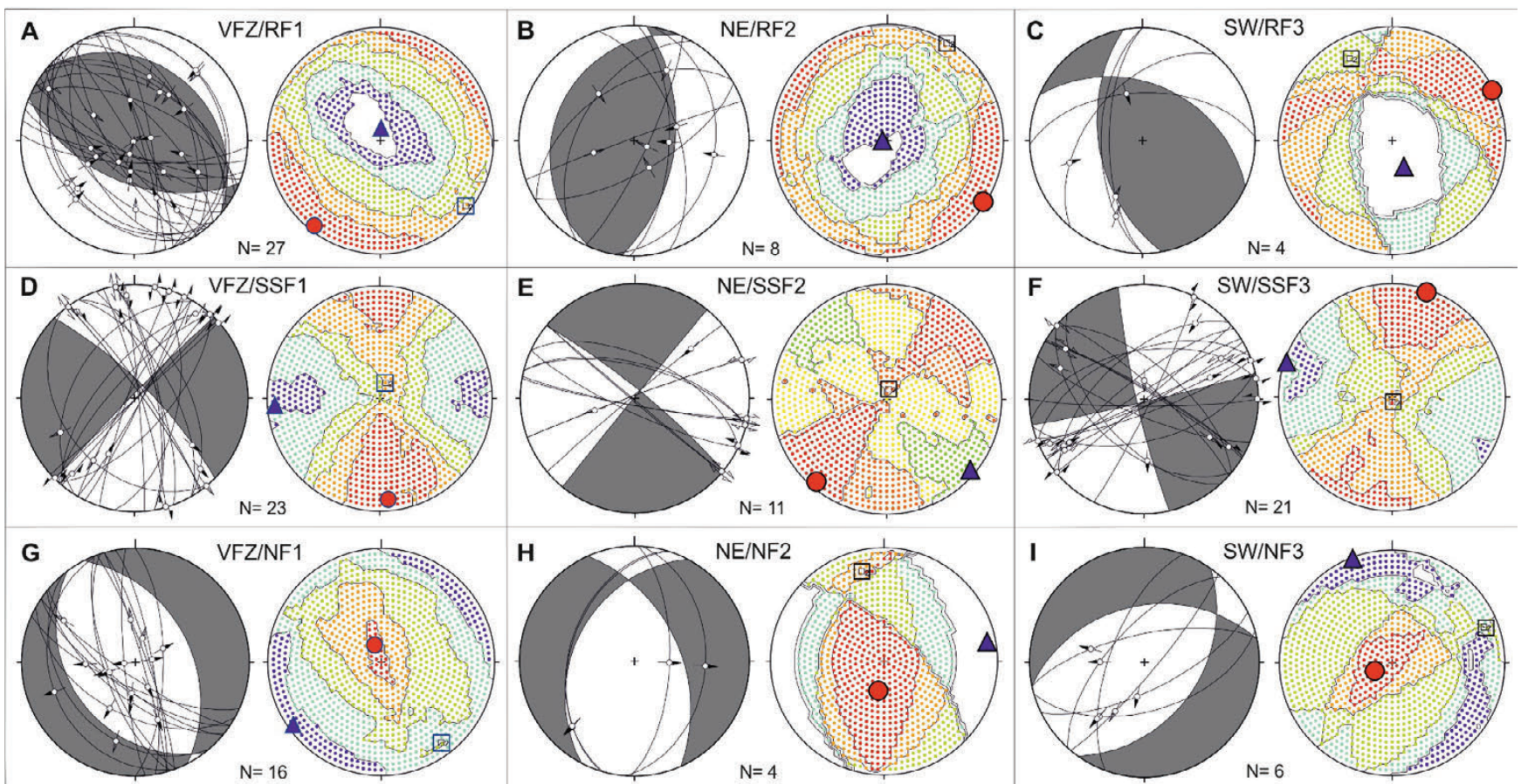

Figure 5. Structural diagrams for the Vinodol fault zone (VFZ), i.e. the NE and SW margins of the Vinodol Valley and Bakar Bay (NEVFZ and SWVFZ - see Fig. 4). The white quadrants on the structural beach-ball diagrams represent compression, while the shaded quadrants represent tension. A) Reverse fault group 1 (VFZ/RF1); B) Reverse fault group 2 (NE/RF2); C) Reverse fault group 3 (SW/RF3); D) Strike-slip fault group 1 (VFZ/SSF1); E) Strike-slip fault group 2 (NE/SSF2); F) Strike-slip fault group 3 (SW/SSF3); G) Normal fault group 1 (VFZ/NF1); H) Normal fault group 2 (NE/NF2); I) Normal fault group 3 (SW/NF3). The red dots, rectangles, and blue triangles indicate $\sigma_{1}, \sigma_{2}$ and $\sigma_{3}$, respectively.

ALLMENDINGER, 1990) as well as derived synthetic structural focal mechanisms, indicated that the observed palaeostress compressional field is associated with a P-axis predominantly trending NE-SW, whereas the T-axis is subvertical, steeply dipping towards the NNW at an angle of $81^{\circ}$ (see Table 1 for details).
The second group of the observed reverse faults (NE/RF2) within the VFZ, along the NE margin of the study area, is generally characterised by two fault group subsets (Fig. 5 and Table 1). The first subset is characterised by an average ESE dip direction and WNW-directed tectonic transport, whereas the second sub-

Table 1. Mean geometric properties of the observed fault planes within the VFZ, i.e. along the NE and SW margins of the Vinodol Valley and Bakar Bay (NEVFZ and SWVFZ) with calculated kinematic indicators and parameters. Fault planes observed in the VFZ zone were delineated with respect to their geometrical properties and kinematic compatibility within the following groups (see Fig. 5):VFZ/RF1 - Reverse fault group 1; NE/RF2 - Reverse faults group; SW/RF3 - Reverse faults group 3; VFZ/SSF1 - Strike-slip faults group 1; E) NE/SSF2 - Strike-slip faults group 2; SW/SSF3 - Strike-slip faults group 3; G) VFZ/NF1 - Normal faults group 1; NE/NF2 - Normal faults group 2; SW/NF3 - Normal faults group 3.Fault types: $\mathrm{R}$ - reverse; SS - strike-slip; $\mathrm{N}$ - normal. Orientation of the P and T-axis are based on constructed synthetic structural beach-ball diagrams.

\begin{tabular}{|c|c|c|c|c|c|c|c|c|c|c|c|c|c|}
\hline \multirow{2}{*}{$\begin{array}{l}\text { Fault } \\
\text { group }\end{array}$} & \multirow{2}{*}{$\begin{array}{l}\text { Fault group } \\
\text { subset }\end{array}$} & \multirow{2}{*}{$\begin{array}{l}\text { No. of fault } \\
\text { data }\end{array}$} & \multirow{2}{*}{$\begin{array}{c}\text { Dip } \\
\text { azimuth }\left({ }^{\circ}\right)\end{array}$} & \multirow{2}{*}{$\begin{array}{c}\text { Dip angle } \\
\left({ }^{\circ}\right)\end{array}$} & \multirow{2}{*}{$\begin{array}{l}\text { Pitch } \\
\left({ }^{\circ}\right)\end{array}$} & \multirow{2}{*}{$\begin{array}{l}\text { Strike } \\
\left({ }^{\circ}\right)\end{array}$} & \multirow{2}{*}{$\begin{array}{l}\text { Fault } \\
\text { type }\end{array}$} & \multicolumn{2}{|c|}{ Striation } & \multicolumn{2}{|c|}{ P-axis } & \multicolumn{2}{|c|}{ T-axis } \\
\hline & & & & & & & & Trend $\left({ }^{\circ}\right)$ & Plunge $\left({ }^{\circ}\right)$ & Trend $\left({ }^{\circ}\right)$ & Plunge $\left({ }^{\circ}\right)$ & Trend $\left({ }^{\circ}\right)$ & Plunge $\left({ }^{\circ}\right)$ \\
\hline \multirow{2}{*}{ VFZ/RF1 } & VFZ/RF1a & 12 & 55 & 55 & 67 & - & \multirow{2}{*}{$\mathrm{R}$} & 82 & 43 & \multirow{2}{*}{222} & \multirow{2}{*}{10} & \multirow{2}{*}{3} & \multirow{2}{*}{81} \\
\hline & VFZ/RF1b & 15 & 219 & 63 & 74 & - & & 216 & 54 & & & & \\
\hline \multirow{2}{*}{ NE/RF2 } & NE/RF2a & 5 & 106 & 60 & 90 & - & \multirow{2}{*}{$\mathrm{R}$} & 106 & 60 & \multirow{2}{*}{121} & \multirow{2}{*}{12} & \multirow{2}{*}{250} & \multirow{2}{*}{80} \\
\hline & $\mathrm{NE} / \mathrm{RF} 2 \mathrm{~b}$ & 3 & 323 & 63 & 60 & - & & 200 & 47 & & & & \\
\hline \multirow{2}{*}{ SW/RF3 } & SW/RF3a & 2 & 270 & 63 & 42 & - & \multirow{2}{*}{$\mathrm{R}$} & 202 & 37 & \multirow{2}{*}{63} & \multirow{2}{*}{02} & \multirow{2}{*}{158} & \multirow{2}{*}{70} \\
\hline & SW/RF3b & 2 & 334 & 52 & 62 & - & & 297 & 43 & & & & \\
\hline \multirow{2}{*}{ VFZ/SSF1 } & VFZ/SSF1a & 12 & - & - & 12 & $44-224$ & \multirow{2}{*}{ S-S } & 111 & 11 & \multirow{2}{*}{175} & 11 & 266 & 05 \\
\hline & VFZ/SSF1b & 11 & - & - & 10 & $136-316$ & & 268 & 9 & & 11 & 200 & Ju \\
\hline $\mathrm{NF} / \mathrm{SSE}$ ? & NE/SSF2a & 3 & - & - & 32 & $42-222$ & $S_{-} S_{1}$ & 124 & 32 & 221 & 06 & 131 & 04 \\
\hline & $\mathrm{NE} / \mathrm{SSF} 2 \mathrm{~b}$ & 8 & - & - & 0 & $131-311$ & כ-נד & 112 & 0 & 221 & 00 & 131 & 04 \\
\hline SHISSEZ & SW/SSF3a & 13 & - & - & 13 & $76-256$ & $S C$ & 144 & 12 & 018 & 03 & 280 & ح0 \\
\hline בזכבנסר & SW/SSF3b & 8 & - & - & 16 & $168-348$ & כ-כ & 185 & 25 & (10 & כ2 & 200 & 02 \\
\hline YEZ/NE1 & VFZ/NF1a & 5 & 78 & 79 & 70 & - & A & 135 & 64 & 230 & 77 & 221 & 02 \\
\hline VI & VFZ/NF1b & 11 & 230 & 63 & 75 & - & IV & 229 & 55 & הכנ & 11 & 234 & כ0 \\
\hline NE/NE? & $\mathrm{NE} / \mathrm{NF} 2 \mathrm{a}$ & 2 & 93 & 51 & 90 & - & $N$ & 93 & 51 & 193 & 68 & 79 & 09 \\
\hline IVL/IVI 2 & NE/NF2b & 2 & 286 & 42 & 35 & - & IN & 223 & 23 & בנדו & 00 & 13 & (0) \\
\hline SW/NF3 & SW/NF3a & 3 & 149 & 69 & 58 & - & $N$ & 208 & 51 & 206 & 76 & בר ד & 01 \\
\hline SWV/NF3 & SW/NF3b & 3 & 317 & 67 & 55 & - & $\mathrm{N}$ & 258 & 48 & 246 & 10 & 339 & 01 \\
\hline
\end{tabular}




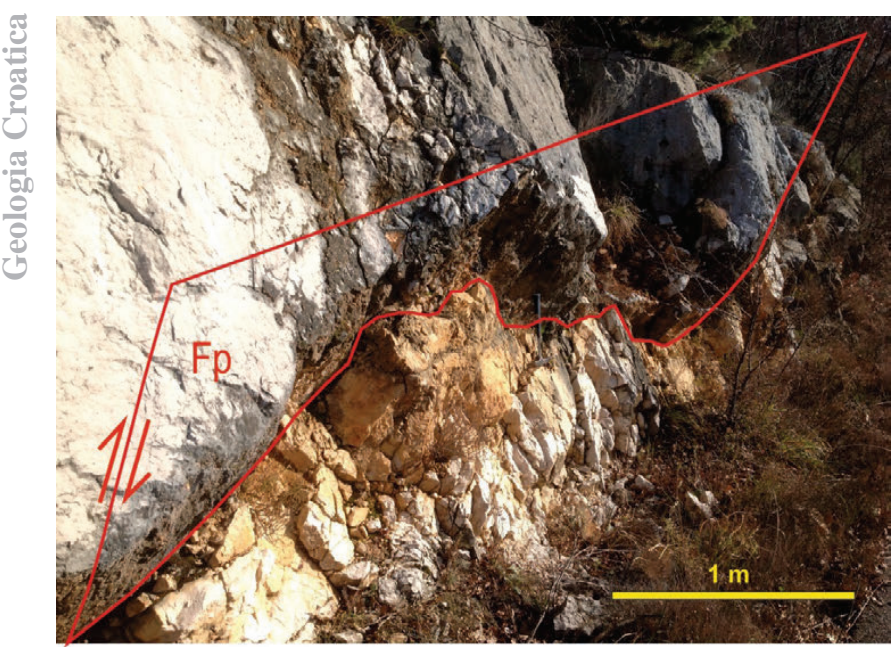

Figure 6. Photograph of the reverse fault plane $(\mathrm{Fp}=37 / 48)$ in recrystallized limestones of the Upper Cretaceous Gornji Humac fm. along the NE margin of the Vinodol Valley. Location: $45^{\circ} 13^{\prime} 22.4^{\prime \prime} \mathrm{N}, 14^{\circ} 42^{\prime} 14.5^{\prime \prime} \mathrm{E}$.

set is characterised with an average NW dip direction and SEdirected tectonic transport. For this group of reverse faults (NE/ RF2), structural analysis of the representative palaeostress field indicates a compressional palaeostress field associated with a Paxis dominantly trending NW-SE, whereas the T-axis is subvertical, i.e. steeply dipping towards the WSW (Fig. 5 and Table 1).

The third group of the reverse faults (SW/RF3) observed along the SW margin of the study area is represented by data from only four measured fault planes. This fault group is subdivided into two group subsets characterised by W-dipping (E-directed tectonic transport) and NW-dipping (SE-directed tectonic transport) fault subsets (Fig. 5 and Table 1). Structural analysis of the representative palaeostress field indicate that the observed fault planes are related to the compressional palaeostress field, associated with the P-axis dominantly trending NE-SW, whereas the T-axis is dipping towards SE (see Table 1 for details).

Besides the reverse fault planes observed along the NEVFZ and SWVFZ, 55 strike-slip fault planes (Figs. 2, 5 and 9) were measured. The observed strike-slip fault planes were also separated according to their geometric properties and kinematic compatibility into three fault groups and six group subsets i.e., three

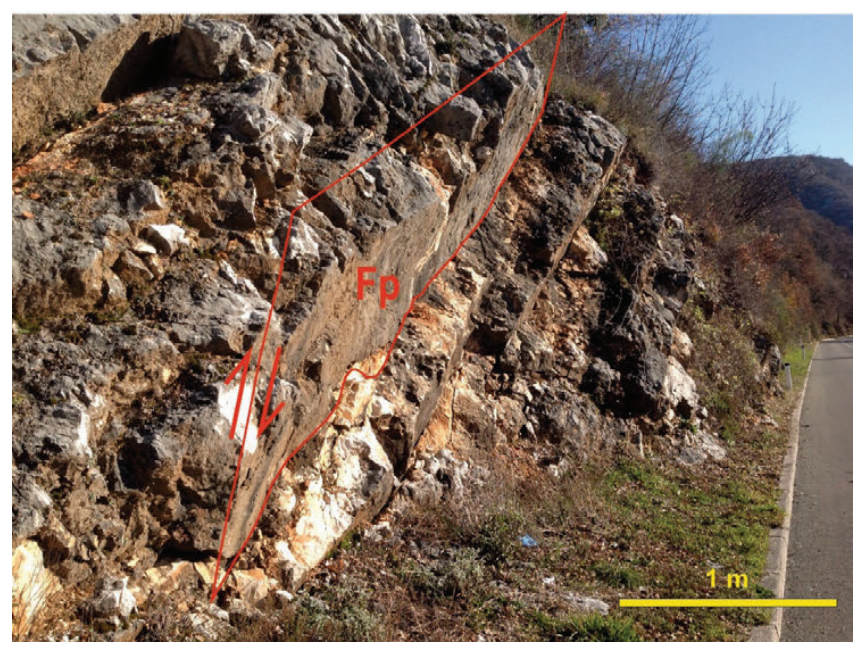

Figure 7. Photograph of the reverse fault plane $(\mathrm{Fp}=24 / 62)$ in the recrystallized limestones of the Gornji Humac fm. along the NE margin of the Vinodol Valley. Location: $45^{\circ} 16^{\prime} 15.5^{\prime \prime} \mathrm{N}, 14^{\circ} 36^{\prime} 14.2^{\prime \prime} \mathrm{E}$.

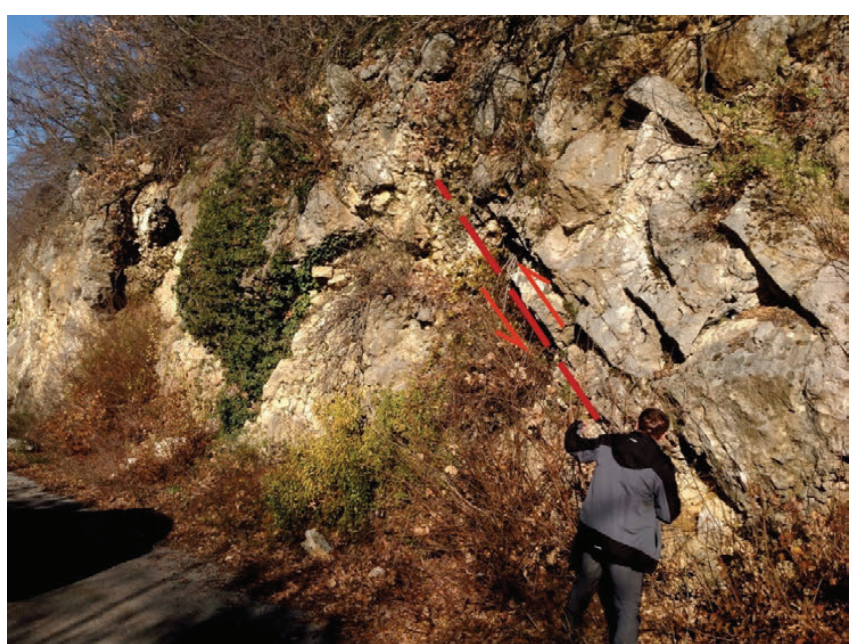

Figure 8. Photograph of the reverse fault plane $(F p=72 / 58)$ in the Upper Cretaceous Milna fm. near the thrust contact with Palaeogene clastic deposits covered with the Quaternary rockfall and deluvial-proluvial deposits. Location: $45^{\circ} 15^{\prime} 32.1^{\prime \prime} \mathrm{N}, 14^{\circ} 37^{\prime} 7.8^{\prime \prime} \mathrm{E}$

conjugate fault pairs (VFZ/SSF1, NE/SSF2 and SW/SSF3; see Fig. 5). Fault groups are characterised by steeply dipping geometry, with average dip angles of $65^{\circ}$ and $80^{\circ}$, respectively. Measured fault planes along the VFZ margins were dominantly striking both NW-SE and NE-SW (VFZ/SSF1 and NE/SSF2; Fig. 5 and Table 1), while along the SW margin of the VFZ third strikeslip fault group resemble a conjugate fault pair with NNW-SSE and ENE-WSW strike (SW/SSF3; Fig. 5 and Table 1).

Mapped strike-slip fault planes were characterised by structural reactivation, with slickenside overgrowths indicating both dextral and sinistral movements (Fig. 10). This implies that for a few observed dextral or sinistral fault surfaces, in addition to the predominant movements they were characterised also by very poorly visible indicators of opposite movement that may indicate occasional interchange of principal stress axes $\sigma_{1}$ and $\sigma_{3}$ within the same stress field.

Kinematic analysis of the observed strike-slip fault planes also supports the concept of structural reactivation, indicating that the identified fault planes may have been formed within two slightly different palaeostress fields: the first one associated with the $\mathrm{N}-\mathrm{S}$ trending $\mathrm{P}$-axis, and the $\mathrm{T}$-axis trending $\mathrm{E}-\mathrm{W}$, and the second one associated with the NE-SW trending P-axis and a Taxis trending NW-SE (see Fig. 5). Field observations and identification of cross-cutting relationships between the mapped reverse and strike-slip faults show that strike-slip fault planes mostly cut across, thereby offsetting reverse fault planes, especially along the SWVFZ (see geological map in Fig. 2). This is particularly noticeable in cases where strike-slip faults (with NE-SW and ENEWSW strikes) are actually oriented perpendicular or at an oblique angle to the reverse faults of the NW-SE strike (see geological map in Fig. 2), suggesting that the observed strike-slip fault plane systems are probably younger than the reverse ones.

Along the NE margin of the VFZ, eight normal fault planes were measured, whereas along its SW margin 18 normal fault planes were observed. Along the NE margin of the Vinodol Valley, normal fault planes were predominantly identified in its SE part, and less in the NW and central parts. Measured normal fault planes within the VFZ characterised by both pure dip-slip and some oblique slip motions could be separated into three fault groups; VFZ/NF1, NE/NF2 and SW/NF3 and six subsets, i.e. three conjugate fault pairs (Fig. 5 and Table 1). 


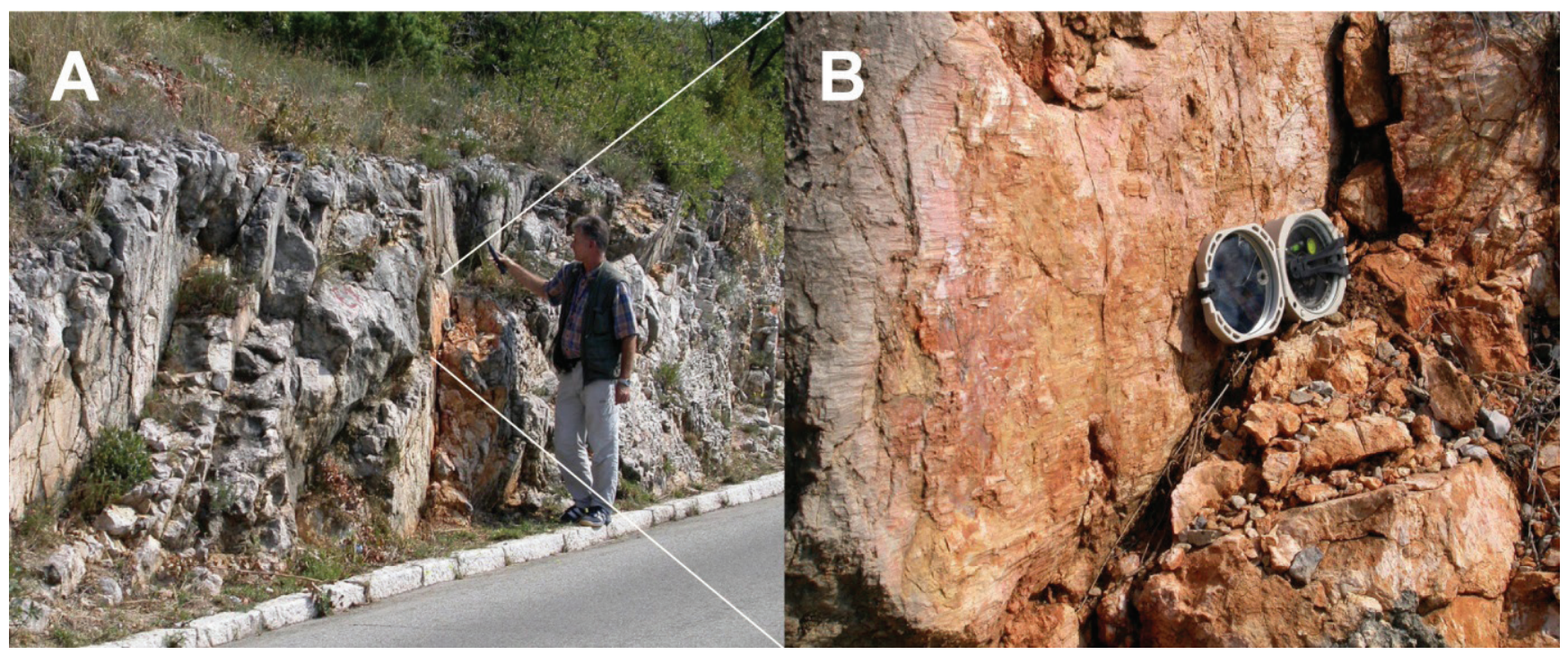

Figure 9. A) Photograph of the fault plane with NW-SE orientation ( $\mathrm{Fp}=55 / 81)$ mapped along the SW margin of the Vinodol Valley; the fault is probably formed in the palaeostress field with the P-axis trending NE-SW, and T-axis trending NW-SE, and subsequently reactivated as a dextral fault within the palaeostress field characterised by the $\mathrm{N}-\mathrm{S}$ trending $\mathrm{P}$-axis, and $\mathrm{E}-\mathrm{W}$ oriented T-axis. B) Detail of the fault plane - subhorizontal striations indicate dextral movement. Recrystallized limestones of the Upper Cretaceous Gornji Humac fm. Location: $45^{\circ} 11^{\prime} 27.4^{\prime \prime} \mathrm{N}, 14^{\circ} 42^{\prime} 4.9^{\prime \prime} \mathrm{E}$. Orientation of bedding is 30/33.

Group 1 (VFZ/NF1; Fig. 5) is characterised by predominantly NW-SE striking fault plane subsets that are steeply dipping towards both NE and SW (Fig. 11 and Table 1). Kinematic analysis shows that these normal fault planes were formed within the palaeostress field characterised by a subvertical P-axis steeply dipping towards the WSW (P-axis orientation is 338/77; Table 1) and subhorizontal T-axis trending NE-SW (see Table 1 for details) that in overall resulted in the NE-SW directed extension.

The Group 2 and group subsets of the normal fault planes (NE/NF2; Table 1) observed along the NE margin of the VFZ are

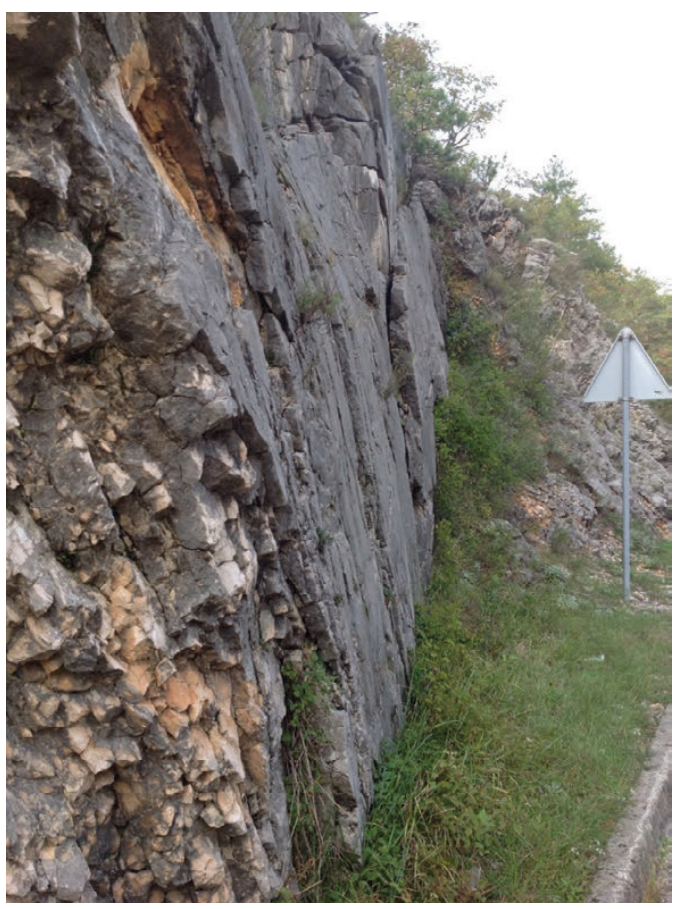

Figure 10. Photograph of the strike-slip fault plane $(\mathrm{Fp}=54 / 85)$ in the recrystallized limestones of the Upper Cretaceous Gornji Humac fm. along the SW margin of the Vinodol Valley. Strike-slip fault plane with both dextral and sinistral movement indicators probably represents a reactivated older fault. Location: $45^{\circ} 11^{\prime} 27.6^{\prime \prime} \mathrm{N}, 14^{\circ} 42^{\prime} 4.4^{\prime \prime} \mathrm{E}$ characterised by a general N-S strike (locally NNE-SSW or NNW-SSE), dipping to the W (WSW) and E with a dip angle of approx. $40-50^{\circ}$ (see Table 1). Kinematic analysis of collected structural data indicated that these fault planes were formed within the palaeostress field associated with the subvertical Paxis (orientation of $\mathrm{P}$-axis is 193/68; see Table 1), and T-axis trending ENE-WSW (see Table 1 for details), resulting in the NE-SW and E-W extension. Due to poor outcrops resulting in ambiguous structural relationships between the Cretaceous and Palaeogene units, identification of the cross-cutting relationships between the observed normal fault planes and reverse and strikeslip fault planes was rather unclear. Large bodies of the Quaternary rockfall material and gravitational slides in the vicinity of measured normal fault planes suggest their potential genetic connection.

The Group 3 and group subsets of the normal fault planes (SW/NF3; Table 1) were observed along the VFZ SW margin (Fig. 5). These conjugate fault pairs are characterised by the NESW striking fault plane subsets (Figs. 5 and 11) dipping both to-

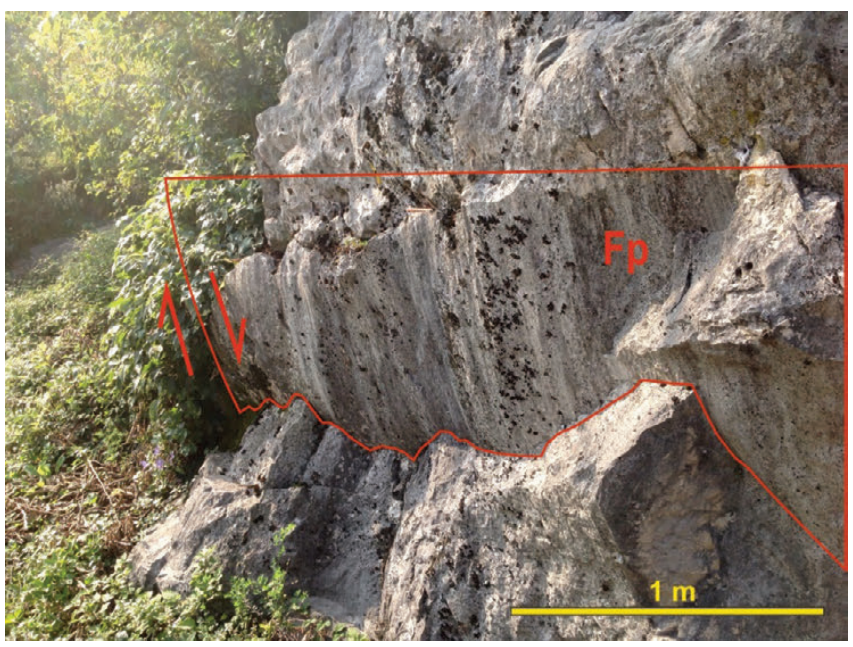

Figure 11. Photograph of the normal fault plane with the NW-SE strike $\left(\mathrm{Fp}=214 / 75 ; \mathrm{I}=80^{\circ}\right.$ from NW) within the Palaeogene Foraminiferal limestones along the SW margin of the Vinodol Valley. Location: $45^{\circ} 9^{\prime} 23.7^{\prime \prime} \mathrm{N}, 14^{\circ} 44^{\prime} 56.5^{\prime \prime} \mathrm{E}$. 
wards the NW and SE (SW/NF2) (see diagrams in Fig. 5). The NE-SW strike is normal to the general strike of the Dinarides (NW-SE; Fig. 5). These normal fault planes were formed within the palaeostress field with a subvertical P-axis steeply dipping towards the SW, whereas the subhorizontal T-axis trends NW-SE (see Table 1 for details). Such a palaeostress field resulted in the NW-SE directed extension.

\section{DISCUSSION}

The results of the geological and structural investigations in the Vinodol Valley and Bakar Bay area indicate the complex tectogenesis of this area through the Palaeogene, Neogene and Quaternary, which led to the formation of the recent geological structure of the area.

\subsection{Geology and palaeogeography of the Vinodol Valley and Bakar Bay}

The NW Adriatic domain, including the study area, represents part of the Mesozoic Adriatic Carbonate Platform (AdCP), and its Late Cretaceous dynamics was caused by the continuous convergence of the Adria Microplate and European Plate (see ŚRODOŃ et al., 2018 and references therein). Changes in the tectonically controlled subsidence between different blocks resulted in the thickness variation of the units, but their general characteristics can be more or less correlated over significant distances across the AdCP (VLAHOVIĆ et al., 2005).

The lower part of the oldest Upper Cretaceous unit, the Cenomanian Milna fm., does not crop out in the study area, and therefore its estimated thickness of more than $250 \mathrm{~m}$ corresponds well with the $>320 \mathrm{~m}$ thick succession determined for the entire unit in Northern Istria (VELIĆ \& VLAHOVIĆ, 1994), 300-400 $\mathrm{m}$ in NW Slovenia (JURKOVŠEK et al., 1996), more than $400 \mathrm{~m}$ of shallow-marine Cenomanian deposits on the island of Cres (FUČEK et al., 2015), 300-350 $\mathrm{m}$ on the island of Unije (FUČEK et al., 2015), 300-350 $\mathrm{m}$ on the island of Vis (KORBAR et al., 2012) and c. $400 \mathrm{~m}$ thick Cenomanian shallow-marine limestones of the Milna fm. determined on the island of Brač (GUŠIĆ \& JELASKA, 1990).

The thickness of overlying limestones with pelagic influence of the Sv. Duh fm., deposited during a regional temporary drowning event near the Cenomanian/Turonian boundary was estimated at $130-150 \mathrm{~m}$ in the study area and also fits with thicknesses determined in other areas: $110-140 \mathrm{~m}$ in Northern Istria (Ćićarija - BRČIĆ et al., 2017), 70-200 m in NW Slovenia (JURKOVŠEK et al., 1996), 30-100 $\mathrm{m}$ on the island of Cres (FUČEK et al., 2015), $40 \mathrm{~m}$ on the island of Vis (KORBAR et al., 2012) or c. $110 \mathrm{~m}$ at the locus typicus of the unit, on the island of Brač (GUŠIĆ \& JELASKA, 1990).

The youngest Cretaceous rocks belonging to the Gornji Humac fm. are exclusively of Turonian age in the study area, since regional emergence between the Cretaceous and Palaeogene (recorded in almost all parts of the Adriatic Carbonate Platform) in this area started relatively early, probably during the Late Turonian (c. $90 \mathrm{Ma}$ ), a bit later than in neighbouring $\mathrm{N}$ Istria (MATIČEC et al., 1996), the $\mathrm{N}$ part of the island of Cres and the island of Krk (ĆOSOVIĆ et al., 1994), as well as in the lower, autochthonous part of the Učka Mt. Such early emergence in the study area provides additional evidence that the area in the central NW part of the AdCP uplifted before the end-Turonian was relatively large, probably covering several thousand $\mathrm{km}^{2}$ (stretching from W and NW Istria to Krk and the Vinodol area). Deposits of the Gornji Humac fm. are consequently in the Vinodol Val- ley relatively thin, from 70 to c. $100 \mathrm{~m}$ (the variable thickness is due to intense karstification during the relatively long stratigraphic hiatus, probably 35 to $40 \mathrm{My}$ ). The top of the Gornji Humac fm. is in other areas of the Adriatic Carbonate Platform usually much younger, mostly Upper Santonian or even Campanian in age, resulting consequently in much thicker deposits - e.g. from 250 to almost $500 \mathrm{~m}$ at their type locality on the island of Brač (GUŠIĆ \& JELASKA, 1990).

The estimated thickness of Palaeogene Foraminiferal limestones of c. $200 \mathrm{~m}$ is thicker than the average thickness of these deposits presented on the Crikvenica sheet of the Basic Geological Map (120 m, ŠUŠNJAR et al., 1970). However, the thickness of Foraminiferal limestones is locally very variable, depending on the palaeorelief, local subsidence and duration of the stratigraphic hiatus - e.g. in the Čikola river section ŠPANIČEK et al. (2017) determined their thickness of $255 \mathrm{~m}$, and DROBNE et al. (1991) measured thicknesses between 230 and $280 \mathrm{~m}$ in the Ravni Kotari area. The thickness of the Transitional deposits (Td) in the Vinodol Valley was estimated at $60 \mathrm{~m}$, and thickness of overlying Flysch deposits (Fd) at $>350 \mathrm{~m}$, which is significantly greater than the average values presented on the Crikvenica sheet of the Basic Geological Map (the thickness of both units was estimated

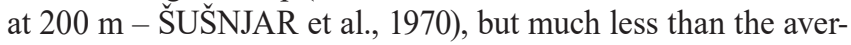
age thicknesses represented on neighbouring maps (Labin: $\mathrm{Td}$ 300-700, Fd 450 m - ŠIKIĆ et al., 1969; Ilirska Bistrica: Td 200 m, Fd 400-650 m - ŠIKIĆ et al., 1972; Rab: Td 150 m, Fd 600 m - MAMUŽIĆ et al., 1969).

\subsection{Structural relationships in the Vinodol Valley and Bakar Bay}

Structural investigations in the Vinodol Valley and its NW prolongation Bakar Bay based on structural data collected on fault planes within the NEVFZ and SWVFZ (Fig. 5) resulted in more than 120 measurements at 127 stations. These structural data were mostly collected along the tectonic contact between the Upper Cretaceous limestones and the Eocene carbonate and clastic deposits and provided field evidence of the tectonic evolution of the study area, which may be also used in understanding the Quaternary evolution of the Vinodol Valley area. Kinematic analysis of fault planes and the overlapping relationships identified in the study area provided not only basic information of palaeostress field changes recorded along the mapped fault systems but also their potential neotectonic activity in respect to the recent stress field.

In the area of the Vinodol Valley and Bakar Bay the first fault group (VFZ/RF1) is represented by the reverse fault planes observed along both margins, which are characterised by striations of both pure dip-slip and oblique-slip kinematics (Fig. 5, see diagram A). Kinematic analysis shows that the first reverse fault group (VFZ/RF1) was characterised by steep conjugate fault planes (c. $55^{\circ}$ and $63^{\circ}$ ) dipping towards the NE and SW, indicating SW- and NE-directed tectonic transport respectively (Fig. 5, diagram A; see Table 1 for details). With the NW-SE strike, reverse fault group subsets, i.e. conjugate fault pairs along the NE margin show dominant SW-directed tectonic transport, while the structural position of the lithostratigraphic units (Fig. 3) and measured fault planes along the main thrusting fault zone along the SW margin of the Vinodol Valley suggest predominant NEdirected tectonic transport (see cross-sections in the Fig. 3).

The second reverse fault plane group (NE/RF2) observed along the NE margin of the VFZ was characterised by conjugate fault planes with a general NE-SW strike, dipping towards the NW and SE (c. $60^{\circ}$ and $63^{\circ}$ ), indicating NW- and SE-directed 
tectonic transport (Fig. 5, diagram B; see Table 1 for details). The third fault plane group (SW/RF3) of reverse faults along the SW margin of the Vinodol Valley and Bakar Bay resemble the reverse fault plane group NE/RF2 observed along the NE margin. The $\mathrm{SW} / \mathrm{RF} 3$ fault group is characterised by subsets dipping generally towards the NW (W) and ESE (c. $63^{\circ}$ and $52^{\circ}$ ), with the tectonic transport towards SE (E) and WNW, respectively (diagram $\mathrm{C}$ in Fig. 5; see Table 1 for details).

Palaeostress field analysis of measured reverse fault planes along the thrust contact of the Upper Cretaceous and Palaeogene carbonates (Foraminiferal limestones) over the younger Palaeogene clastic deposits suggest the compressional stress field and structures formed within both NE-SW trending and NW-SE trending compression (diagrams A, B and C in Fig. 5; see Table 1 for details). Structures related to the NE-SW trending compression probably correlate with the principal 'Dinaridic tectonic phase' (sensu BLAŠKOVIĆ, 2005 and references therein), which during the Late Cretaceous and Palaeogene resulted in the build up of the major fault and fold related NW-SE striking structures in the Dinarides, being characterised by NE-dipping geometry and SW-directed tectonic transport (PRELOGOVIĆ et al., 1981, 1982, 1995; BLAŠKOVIĆ, 2005; ŽIBRET \& VRABEC, 2016).

Though typical NW-SE striking, NE-dipping structures were previously observed within the Vinodol Valley and Bakar Bay (BLAŠKOVIĆ, 1991, 1997, 1999, 2005; PRELOGOVIĆ et al., 1981, 1982, 1995), this study identified numerous fault planes within the VFZ that are steeply dipping (c. $60^{\circ}$ ) towards the SW and are characterised by NE-directed tectonic transport. These new findings confirm that during the tectonic evolution of the External Dinarides, structures with NE-directed tectonic transport have been formed in some areas (as in the neighbouring Velebit Mt. area - VLAHOVIĆ et al., 2012; ŚRODOŃ et al., 2018; TOMLJENOVIĆ et al., 2018) along with the predominant SWdirected tectonic transport. Such structures were formed either concurrently with SW-vergent Dinaridic structures or their formation may present a substage within the principal Dinaridic tectonic phase.

The second observed reverse fault plane group in this work characterised by NW (W) and NE, ESE dip directions (diagrams $\mathrm{B}$ and $\mathrm{C}$ in Fig. 5; see Table 1 for details) correlates with results reported by BLAŠKOVIĆ (1998). In reported study author described existing Dinaridic structures as refolded and faulted structures which were deformed during the 'late Dinaridic phase' as a result of the regional stress field change from NE-SW trending compression to WNW-ESE trending compression

Beside the measured reverse fault planes in the area of the Vinodol Valley and Bakar Bay numerous strike-slip fault planes were also observed in this study. In accordance with the geometric properties and kinematics within the Vinodol fault zone delineated strike-slip fault groups were characterised by subvertical geometry and slickensides showing structural reactivation, i.e., both dextral and sinistral motions. Characterised by the NW-SE strike (dipping towards both NE and SW) and perpendicular strike NE-SW (dipping towards both NW and SE), kinematic analysis of the observed strike-slip fault planes indicated a similar palaeostress field to the observed reverse fault plane groups, being characterised by N-S, NE-SW, and NNE-SSW trending P-axis (diagrams D, E, and F in Fig. 5; see Table 1 for details). These results may suggest that at least some of observed strikeslip fault planes in the study area resemble structurally reactivated inherited reverse fault planes within the transpressional/ transtensional stress field.
However, at the same time, due to their subvertical geometry and present field observations of cross-cutting relationships between mapped reverse and strike-slip fault planes, we believe that the observed strike-slip fault planes in the study area are probably younger than the reverse faults because most of them cross-cut and laterally displace measured reverse fault planes (Fig. 3). At the same time, the geometry of mapped strike-slip faults and computed stress field characterised by N-S, NE-SW, and NNESSW trending P-axis is in accordance with the observed strikeslip and reverse fault planes in the NW External Dinarides of Slovenia, where $\mathrm{N}-\mathrm{S}$ oriented compression during the Pliocene and Quaternary has also been indicated (ŽIBRET \& VRABEC, 2016). According to PRELOGOVIĆ et al. (1981, 1982, 1995), the mapped NW-SE and NE-SW striking strike-slip faults in the Vinodol Valley and Bakar Bay are parts of the Ilirska BistricaRijeka-Senj seismogenic fault zone and resemble neotectonically active faults in the study area.

Mapped normal faults in the Vinodol Valley and Bakar Bay were characterised by NW-SE and NE-SW (locally N-S, NNESSW and NNW-SSE) striking planes that accommodated pure dip-slip/oblique motions (diagrams G, H and I in Fig. 5; see Table 1) and NE-SW and NW-SE (locally E-W) trending extension. Though the structural relationships between reverse and strikeslip fault groups with respect to the normal faults are not clear, it can be assumed that NE-SW, E-W and NW-SE directed extension may be considered as a local feature associated with gravitational collapse of the hanging wall structural sequence, i.e. hinge zones of the hosting anticlines. In our opinion, such gravitationally conditioned extension (cf. TAVANI et al., 2012 and references therein) may be either potentially concurrent to active folding and formation of the Vinodol Valley and Bakar Bay area during the Late Cretaceous and Palaeogene or it was associated with the younger tectonic phase characterised by radial extension of the folded structure after/before compressional/transpressional tectonics which commenced in the Pliocene and Quaternary. According to VAN UNEN et al. (2019) and their observations in the area of the Internal Dinarides, the extension of folded structures in the Dinarides occurred during the late Cretaceous-Oligocene, simultaneously or slightly after the main orogeny build up, but definitely before the Pliocene-Quaternary transpression. Furthermore, in the vicinity of the observed normal fault planes, large bodies of Quaternary rockfall material and gravitational slides have been mapped, which according to BLAŠKOVIĆ (1997) may suggest their potential role in the increasing rock instability and failure.

Results of the structural study conducted and presented in this paper are generally in accord with the existing knowledge on the local/regional tectonic evolution in this part of the External Dinarides (PRELOGOVIĆ et al., 1981, 1982, 1995; BLAŠKOVIĆ, 2005; ŽIBRET \& VRABEC, 2016; VAN UNEN et al., 2019). However, our structural results address the presence of compressional structures characterised by both SW and NE-directed tectonic transport. Our field observations of the cross-cutting relationships between mapped reverse and strike-slip fault planes also suggest that the observed strike-slip fault planes in the study area are probably younger than the reverse fault planes. Alternatively, the measured normal fault planes may be associated with gravitational collapse within the hinge zones of the hosting anticlines during the late Cretaceous-Oligocene, simultaneously or slightly after orogeny build up, however, before the PlioceneQuaternary transpression. 


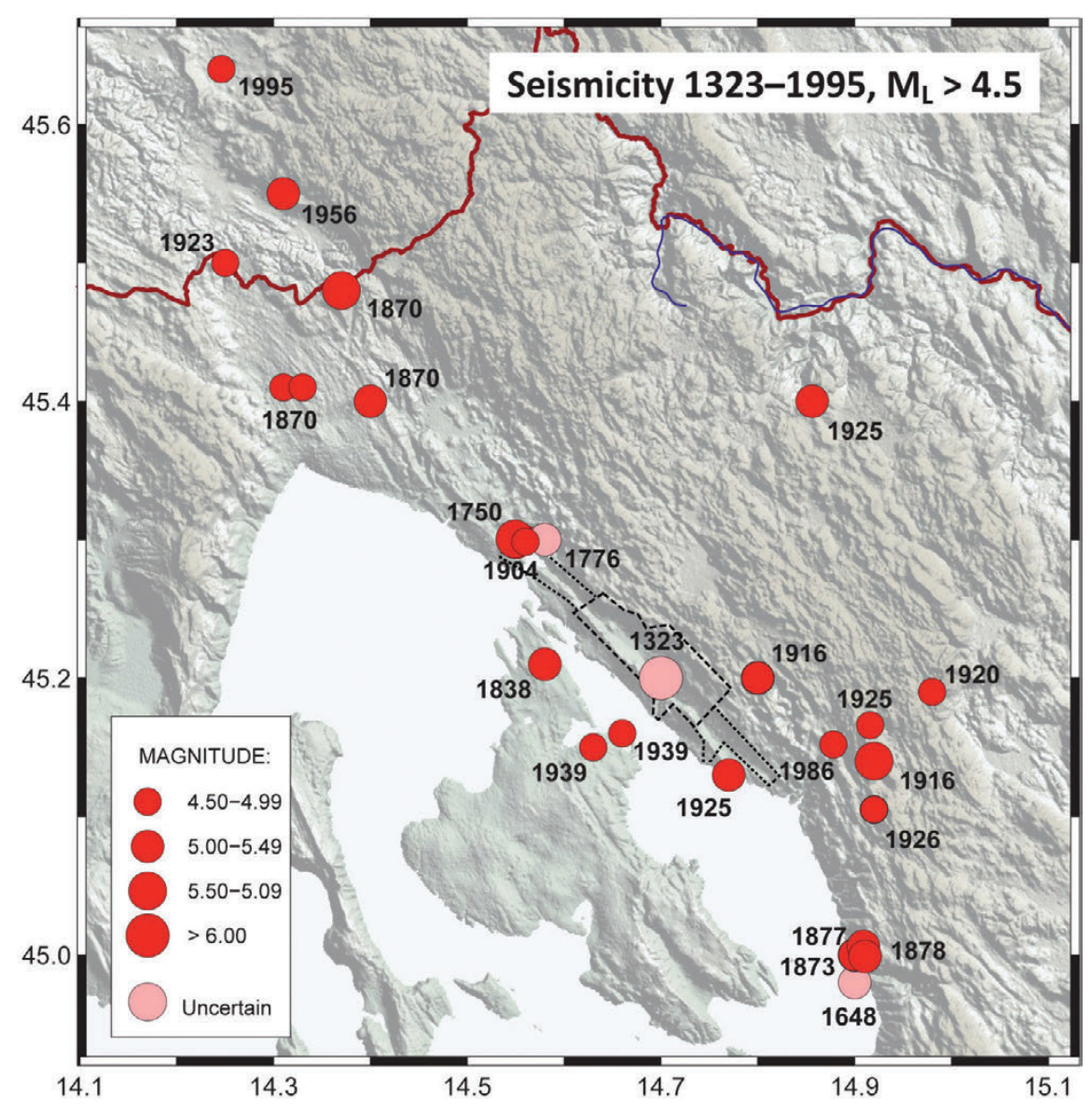

Figure 12. Historical seismicity (1323-1908) and epicentres of instrumentally recorded earthquakes (until 1995) with magnitudes $M_{L}>4.5$ in the wider Vinodol region. The year of earthquake occurrence is indicated by each epicentre. The events of 1323, 1648, and 1776 are considered uncertain (see text). Magnitudes of the pre-instrumental earthquakes are estimated from the observed intensities. After the Croatian Earthquake Catalogue (first described by HERAK et al., 1996, updated annually thereafter).

\subsection{Comparison of palaeostress field analysis and seismological data}

In order to address the potential neotectonic activity of faults within the VFZ and their possible favourable orientation within the recent stress field, we hereby compare our results of palaeostress field analysis with the available seismological data from the wider study area.

The ongoing tectonic activity in the greater Vinodol area (including the epicentral areas of Ilirska Bistrica-Klana, Rijeka, Bakar, Vinodol, Krk and Senj) is expressed by moderate seismicity, with hypocentres in the upper crust, mostly shallower than $20 \mathrm{~km}$. It is well documented in the corresponding entries in the Croatian Earthquake Catalogue (CEC, first described by HERAK et al., 1996, updated annually thereafter) and by numerous seismicity-related studies (e.g. MARKUŠIĆ \& HERAK, 1999; IVANČIĆ et al., 2006, 2018; KASTELIC et al., 2013; HERAK \& HERAK, 2017 and references therein).

Figure 12 shows that significant earthquakes are known to have occurred here in the past. The most important ones (from the point of view of this study) are the events of 1323, 1750, 1870, and 1916. The strongest of them could have been that of 1323 (the 'Vinodol earthquake') which is often listed as causing intensity as high as IX ${ }^{\circ}$ MSK. Although this earthquake probably indeed occurred and caused considerable damage, it is unfortunate that only very sparse information exists about it (merely a sentence in the glagolitic document from Grižane), so we treat both the location and the magnitude as unreliable. The large Bakar earthquake of November 28, $1750\left(\mathrm{I}_{0}=\right.$ VII-VIII MSK) has been studied in detail by HERAK et al. (2017), so here we will only mention the fact that about 3000 aftershocks were felt in the three years following it. The Klana mainshock of 1870 (March 1, 1870, I $=$ VIII MSK, HERAK et al., 2018) was the last significant earthquake in the Ilirska Bistrica-Klana area. It is still vividly remembered by the local inhabitants, and is one of key events for understanding seismic hazard in the greater Rijeka area. The most recent one occurred on March 12, 1916 about $10 \mathrm{~km}$ east of Novi Vinodolski, with the epicentral intensity $\mathrm{I}_{0}=$ VIII MSK. Most damage was reported from Grižane (over 100 houses damaged) and Bribir (in the ENE part of the Vinodol Valley, within the NE Vinodol Fault Zone (NEVFZ) area - see Fig. 4).

Contemporary seismicity follows the same pattern (Fig. 13), however, with no event exceeding magnitude 4.8 for over two decades. Nevertheless, significant densification of the network of seismological stations in Croatia and Slovenia in this time period, enabled lowering the detection threshold well below magnitude 1.0 in some areas. This, in turn, made it possible to collect information on details of seismogenic faults properties even during their periods of low activity. In particular, the observed spatial distribution of the first P-wave polarity could have been inverted for a number of rather small events (Fig. 13), and advanced location methods (e.g. HERAK \& HERAK, 2017) were used to learn more about the geometry of active faults.

Focal mechanism solutions (FMS, shown in Fig. 13) have been computed by inverting the observed spatial distribution of 


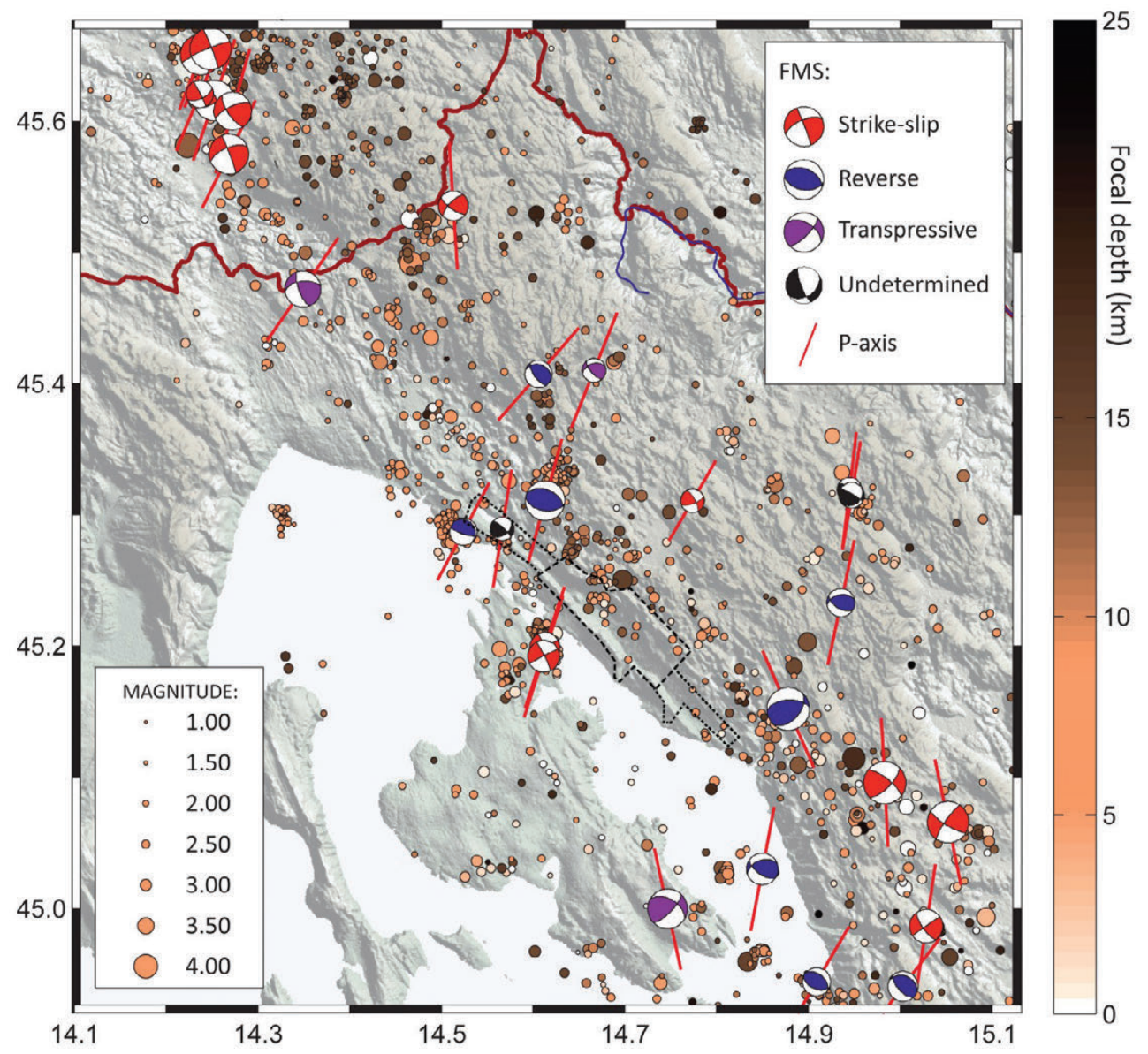

Figure 13. Seismicity in the period 1996-2017 ( $\left.\mathrm{M}_{\mathrm{L}}>0.0\right)$. The hypocentral depth is represented by the symbol colour according to the colour scale on the right. Only events located by at least 8 reported phase onsets, and having azimuthal gap of reporting stations smaller than $120^{\circ}$ are shown. The beach-ball diagrams (1986-2017) represent focal mechanism solutions (FMS) as lower hemisphere, stereographic projection of the sense of the P-wave first motion onto the focal sphere (compressive quadrants are shaded). See the legend for colour-coding of the mechanism type. Red lines show inferred orientation of the P-axes for each FMS.

the first longitudinal wave polarity for the best fit double-couple source geometry (FMS-Database, 2019). The P-axes computed from FMS are often taken as the first order proxy (within about $\pm 15^{\circ}$ ) for the direction of local tectonic movement. Judging from their spatial distribution as presented in Fig. 13, the tectonic stress field is relatively homogeneous and horizontal (average plunge $1.5^{\circ}$ ), with a mean orientation close to $\mathrm{N}-\mathrm{S}\left(\mathrm{N} 13^{\circ} \mathrm{E}\right)$. Individual deviations from this direction may be a consequence of local stresses, pre-existing weak fractures (especially for small earthquakes), variations in pore pressure, influence of friction during faulting, or simply the inversion uncertainty.

The suggested types of faulting, on the other hand, are far from homogeneous over the study region. While in the NW part of the considered area (in Slovenia) all FMS are consistent with right-lateral strike-slip faulting along the SE-NW striking subvertical faults (e.g. the Raša fault), further to the SE there is a mixture of transpressive, almost pure dip-slip, and strike-slip faulting. In a compressional tectonic setting this is indicative of a generally transpressive regime, where the $\sigma_{2}$ and $\sigma_{3}$ principal stresses are of similar magnitude, and often only details determine which one is vertical. Indeed, our study area (and the greater Kvarner-Velebit region) may be regarded as the transitional zone of transpression where predominantly reverse and thrust mechanisms of the southern External Dinarides gradually switch into pure strike-slip in the NW Dinarides of southern Slovenia. In such environments, instead of oblique faulting, the stress release may also be decoupled between parallel striking thrust and strike-slip faults. According to MICHAEL (1990), assuming equality of resistance to sliding on both faults and the angle of convergence between $50^{\circ}$ and $35^{\circ}$ (as is the case here), decoupled faulting will be preferred over oblique faulting for thrusts with dip angles lower than 20-30 ${ }^{\circ}$ BECK's (1983) estimates are more permissive and favour decoupling even for steeper dipping faults. This process may be plausible in some cases here, especially for focal depths exceeding about $5 \mathrm{~km}$ or if the strike-slip fault is considerably weaker than the thrust.

Synthetic focal mechanisms constructed by applying the Right Dihedra Method (ANGELIER \& MECHLER, 1977) (see Fig. 5) show good correspondence with the available focal mechanism solutions (Fig. 13). Both synthetic focal mechanism and available focal mechanism solutions for instrumentally recorded earthquakes within the larger Rijeka-Vinodol area and Kvarner Bay suggest that the principal NW-SE and NE-SW striking seismogenic sources (defined by mapping as reverse and strike-slip faults) are compressional and transpressional structures, which are recently tectonically active within the compressional stress field, characterised by a generally $\mathrm{N}-\mathrm{S}$ oriented $\mathrm{P}$-axis.

\section{CONCLUSIONS}

In the area of the Vinodol Valley and Bakar Bay geological and structural investigations highlight the complex tectonic evolution of this area not only through the Palaeogene and Neogene, but also during the Quaternary period.

Upper Cretaceous informal lithostratigraphic units mapped in the study area can be well correlated with units proposed by 
GUŠIĆ \& JELASKA (1990), except for the much shorter stratigraphic range of the youngest unit, the Gornji Humac fm. Upper Turonian age of the youngest Cretaceous rocks in the Vinodol Valley suggest that the uplifted area in the central NW part of the Adriatic Carbonate Platform at the end of Turonian already covered several thousands $\mathrm{km}^{2}$ (from W and NW Istria to the Krk and Vinodol area).

Results of the structural investigation in general correspond to those of previous studies and existing knowledge about the tectonic evolution of the Dinarides, including several important new findings.

In the area of the Vinodol Valley and Bakar Bay, the majority of the observed reverse fault planes were characterised by both pure dip-slip and oblique-slip kinematics. Kinematic analysis shows that the first reverse fault groups were characterised by steep planes $\left(\right.$ c. $60^{\circ}$ ) dipping either towards the NE or the SW indicating SW- and NE-directed tectonic transport respectively. The NE-directed tectonic transport was determined along mapped structures within both the NE and SW margins of the Vinodol Valley. However, according to the structural and stratigraphic relationships of the mapped lithostratigraphic units along the SW margin of the Vinodol Valley we address faulted structures as predominantly NE-vergent structures. Both NE and SW dipping structures are related to a NE-SW trending compression stress field that probably formed within the Dinaridic tectonic phase (BLAŠKOVIĆ 2005; ŽIBRET \& VRABEC, 2016). Newly mapped SW-dipping structures indicate that beside the predominant SW-vergent structures in the Dinarides, NE-vergent structures formed either concurrent to the SW-vergent structures or were associated with a separate sub-stage within the principal Dinaridic phase that also existed in the study area.

The second mapped reverse fault plane groups in the study area are characterised by both NW (W) and ESE dip directions, and SE (E) and WNW directed tectonic transport respectively. These fault plane subsets resemble conjugate fault pairs formed within both NE-SW and NW-SE trending compression. According to BLAŠKOVIĆ (1998) these Dinaridic structures were formed in the 'late Dinaridic phase' of the refolding and faulting of existing Dinaridic structures due to a change in regional stress field from NE-SW trending compression to WNW-ESE trending compression.

In the area of the Vinodol Valley and Bakar Bay, strike-slip fault planes were also observed. Strike-slip fault groups characterised by subvertical geometry show structural reactivation, i.e. both dextral and sinistral motions. NW-SE striking (dipping both towards NE and SW) and NE-SW striking fault planes indicate a palaeostress field characterised by NE-SW, N-S and a NNWSSE trending P-axis, similar to the observed reverse fault planes. Orientation of the $\mathrm{P}$-axis associated with the transpressional/transtensional stress field may suggest that mapped strike-slip fault planes in the study area resemble structurally reactivated older reverse fault planes. At the same time, the fault subvertical geometry and cross-cutting relationships between mapped reverse and strike-slip fault planes suggests that the strike-slip structures are probably the younger ones.

Measured normal fault planes in the study area characterised by generally NW-SE and NE-SW striking planes (NE-SW and NW-SE directed extension) and may have been caused by gravitational collapse of hanging wall structures in the hinge zones of the anticline (TAVANI et al., 2012 and references therein) during the orogen build up (VAN UNEN et al., 2019) or slightly after, however before the Pliocene-Quaternary transpression with dominant strike-slip motions.
Comparison of palaeostress field analysis and constructed synthetic focal mechanism with available data on focal mechanism solutions within the Ilirska Bistrica-Rijeka-Senj seismogenic fault zone shows the favourable orientation of observed NW-SE and NE-SW striking faults with respect to recent compressional/transpressional stress field (N-S oriented P-axis) suggesting they may be potential seismogenic sources within the study area.

\section{ACKNOWLEDGEMENT}

This paper resulted from work on two scientific projects funded by the Croatian Science Foundation (HRZZ): VELEBIT (Grant no. IP-2014-09-9666, PI Professor Marijan HERAK) and GEOSEKVA (Grant no. IP-2016-06-1854, PI Dr. Tvrtko KORBAR), and the authors are grateful for all support in the field and cabinet research. The authors would like to thank Dr. Ana MLADENOVIĆ (University of Belgrade) and Professor Marko VRABEC (University of Ljubljana) for their very constructive remarks and comments that considerably improved the quality of this manuscript. We would like to thank colleagues Nenad OŠTRIĆ and Dr. Tvrtko KORBAR from the Croatian Geological Survey (CGS), who were part of the Vinodol Valley area geological mapping team. We would also like to thank Dr. Georg KOCH (CGS) for useful advice and Dr. Ajka ŠORŠA (CGS) for preparation of the Vinodol Valley geological map.

\section{REFERENCES}

ANGELIER, J. \& MECHLER P. (1977): Sur une méthode graphique de recherche des contraintes principales également utilisable en tectonique et en séismologie: La méthode des dièdres droits.- Bull. Soc. Géol. France, 19, 1309-1318. doi:10.2113/ gssgfbull.S7-XIX.6.1309

BECK, M.E. Jr. (1983): On the mechanism of tectonic transport in zones of oblique subduction.- Tectonophysics, 93, 1-11. doi: 10.1016/0040-1951(83)90230-5

BLAŠKOVIĆ, I. (1991): Raspored uzdužnih, reverznih i normalnih rasjeda i konstrukcija oblika i dubina plohe podvlačenja (Disposition of the longitudinal, reverse and normal faults and the construction of the forms and depth of the underthrusting surfaces).- Geol. vjesnik, 44, 247-256, Zagreb.

BLAS̆KOVIĆ, I. (1997): The helicoidal fault systems of Vinodol (Croatia) and their genesis.- Geol. Croatica, 50/1, 49-56, Zagreb.

BLAS̆KOVIĆ, I. (1998): The two stages of structural formation of the costal belt of the External Dinarides.- Geol. Croatica, 51/1, 75-89, Zagreb.

BLAŠKOVIĆ, I. (1999): Tectonics of part of the Vinodol valley within the model of the continental crust subduction.- Geol. Croatica, 52/2, 153-189, Zagreb.

BLAŠKOVIĆ, I. (2005): Geologija Vinodola (Geology of Vinodol).- In: BIONDIĆ, R., VLAHOVIĆ, I. \& VELIĆ, I. (eds.): 3. Hrvatski geološki kongres (Third Croatian Geological Congress), Vodič ekskurzija (Excursion Guide-Book), 39-48, Zagreb.

BRČIĆ, V., GLUMAC, B., FUČEK, L., GRIZELJ, A., HORVAT, M., POSILOVIĆ, H. \& MIŠUR, I. (2017): The Cenomanian-Turonian boundary in the northwestern part of the Adriatic Carbonate Platform (Ćićarija Mtn., Istria, Croatia): characteristics and implications.-Facies, 63:17. doi: 10.1007/s10347-017-0499-7

ĆOSOVIĆ, V., BALONČIĆ, D., KOIĆ, M., MARJANAC, T., MORO, A., GUŠIĆ, I. \& JELASKA, V. (1994): Paleontological evidence of Paleogene transgression on Adriatic carbonate platform.- Géologie Méditerranéenne, 21/3-4, 49-53. doi: 10.3406/geolm.1994.1524

DROBNE, K., VLAHOVIĆ, I., TRUTIN, M., PAVLOVEC, R., ĆOSOVIĆ, V., BABAC, D., CIMERMAN, F., LUČIĆ, D. \& PAVŠIČ, J. (1991): Excursion B - Ravni Kotari, Paleogene.- In: VLAHOVIĆ, I. \& VELIĆ, I. (eds.): Some aspects of the shallow water sedimentation on the Adriatic carbonate platform (Permian to Eocene), Excursion Guide-Book, The second international symposium on the Adriatic carbonate platform - relations with adjacent regions, 51-105, Zagreb.

FMS-Database (2019): Database of Focal Mechanism Solutions.- Archives of the Department of Geophysics, Faculty of Science, University of Zagreb.

FUČEK, L., MATIČEC, D., VLAHOVIĆ, I., OŠTRIĆ, N., PRTOLJAN, B., KOROLIJA, B., KORBAR, T., HUSINEC, A. \& PALENIK, D. (2015): Osnovna geološka karta Republike Hrvatske mjerila 1:50.000 - list Cres i Lošinj [Basic Geological Map of the Republic of the Croatia 1:50,000 Scale - Cres and Lošinj sheet - in Croatian].- Hrvatski geološki institut, Zavod za geologiju. ISBN: 978-953-690753-3, Zagreb.

GRIMANI, I., ŠUŠNJAR, M., BUKOVAC, J., MILAN, A., CRNOLATAC, I., ŠIKIĆ, D. \& BLAŠKOVIĆ, I. (1973): Osnovna geološka karta SFRJ 1:100.000. Tumač za list Crikvenica L33-102 [Basic Geological Map of the SFRY 1:100,000; Geol- 
ogy of the Crikvenica Sheet - in Croatian].- Institut za geološka istraživanja Zagreb (1963), Savezni geološki zavod, Beograd, 47 p.

GUŠIĆ, I. \& JELASKA, V. (1990): Stratigrafija gornjokrednih naslaga otoka Brača u okviru geodinamske evolucije Jadranske karbonatne platforme (Upper Cretaceous stratigraphy of the Island of the Brač).- Jugosl. akad. znan. i umjet., Institut za geološka istraživanja, OOUR za geologiju, str. 160, Zagreb.

HAQ, B.U., HARDENBOL, J. \& VAIL, P.R. (1987): Chronology of fluctuating sea levels since the Triassic.- Science, 235, 1156-1167. doi: 10.1126/science.235.4793.1156

HARDENBOL, J., THIERRY, J., FARLEY, M.B., JACQUIN, T., DE GRACIANSKY, P.C. \& VAIL, P. (1998): Mesozoic and Cenozoic sequence chronostratigraphic framework of European basins.- In: GRACIANSKY, P.C. et al. (eds.): Mesozoic and Cenozoic Sequence Stratigraphy of European Basins, SEPM Special Pub., 60, 3-13, charts 1-8. doi: 10.2110/pec.98.02.0003

HERAK, M. \& HERAK, D. (2017): Seismicity and seismic sources in the greater Kvarner-Velebit area, Croatia: Recent advances.- In: 5th Regional scientific meeting on Quaternary geology dedicated to geohazards - Abstracts, Zagreb, 20-21.

HERAK, M., HERAK, D. \& MARKUŠIĆ, S. (1996): Revision of the earthquake catalogue and seismicity of Croatia, 1908-1992.- Terra Nova, 8, 86-94.

HERAK, D., SOVIĆ, I., CECIĆ, I., ŽIVČIĆ, M., DASOVIĆ, I. \& HERAK, M. (2017): Historical seismicity of the Rijeka region (Northwest External Dinarides, Croatia) - Part I: Earthquakes of 1750, 1838, and 1904 in the Bakar epicentral area.- Seismological Research Letters, 88/4, 1-12. doi: 10.1785/0220170014

HERAK, M., ŽIVČIĆ, M., SOVIĆ, I., CECIĆ, I., DASOVIĆ, I., STIPČEVIĆ, J. \& HERAK, D. (2018): Historical seismicity of the Rijeka region (NW External Dinarides, Croatia) - Part II: The Klana earthquakes of 1870.-Seismological research letters, 89/4, 1524-1536. doi:10.1785/0220180064

HGI (2009): Geološka karta Republike Hrvatske, M 1:300.000 [Geological Map of the Republic of Croatia, 1:300,000 scale - in Croatian].- Hrvatski geološki institut (Croatian Geological Survey), Department of Geology, Zagreb.

IVANČIĆ, I., HERAK, D., MARKUŠIĆ, S., SOVIĆ, I. \& HERAK, M. (2006): Seismicity of Croatia in the period 2002-2005.- Geofizika, 23/2, 1-17.

IVANČIĆ, I., HERAK, D., HERAK, M., ALLEGRETTI, I., FIKET, T., KUK, K., MARKUŠIĆ, S., PREVOLNIK, S., SOVIĆ, I., DASOVIĆ, I. \& STIPČEVIĆ, J. (2018): Seismicity of Croatia in the period 2006-2015.- Geofizika, 35/1, 69-98. doi:10.15233/gfz.2018.35.2

JURKOVŠEK, B., TOMAN, M., OGORELEC, B., ŠRIBAR, L., DROBNE, K., POLJAK, M. \& ŠRIBAR, Lj. (1996): Formacijska geološka karta južneg dela Tržaškokomenske planote, Kredne in paleogenske karbonatne kamnine 1:50.000 [Geological Map of the Southern Part of the Trieste-Komen Plateau. Cretaceous and Paleogene Carbonate Rocks 1:50,000 Scale - in Slovenian].- Inštitut za geologijo, geotehniko in geofiziko Ljubljana, $143 \mathrm{p}$.

KASTELIC, V., VANNOLI, P., BURRATO, P., FRACASSI, U., TIBERTI, M.M. \& VALENSISE, G. (2013): Seismogenic sources in the Adriatic Domain.- Mar. Petrol. Geol., 42, 191-213. doi: 10.1016/j.marpetgeo.2012.08.002

KORBAR, T., BELAK, M., FUČEK, L., HUSINEC, A., OŠTRIĆ, N., PALENIK, D. \& VLAHOVIĆ, I. (2012): Osnovna geološka karta Republike Hrvatske mjerila 1:50.000 - list Vis 3 i Biševo 1 [Basic Geological Map of the Republic of the Croatia 1:50000 Scale - Vis 3 and Biševo 1 sheet - in Croatian].- Hrvatski geološki institut, Zagreb.

MAMUŽIĆ, P., MILAN, A., KOROLIJA, B., BOROVIĆ, I. \& MAJCEN, Ž. (1969): Osnovna geološka karta SFRJ 1:100.000, list Rab L 33-114 [Basic Geological Map of SFRY 1:100,000 Scale, Rab Sheet - in Croatian].- Institut za geološka istraživanja Zagreb (1959-1965), Savezni geološki zavod Beograd.

MARKUŠIĆ, S. \& HERAK, M. (1999): Seismic Zoning of Croatia.- Natural Hazards, $18,269-285$.

MARRETT, R. \& ALLMENDINGER, R.W. (1990): Kinematic analysis of fault-slip data.Journal of Structural Geology, 12, 973-986. doi:10.1016/0191-8141(90)90093-E

MATIČEC, D., VLAHOVIĆ, I., VELIĆ, I. \& TIŠLJAR, J. (1996): Eocene limestones overlying Lower Cretaceous deposits of western Istria (Croatia): Did some parts of present Istria form land during the Cretaceous?- Geologia Croatica, 49/1, 117127.

MICHAEL, A.J. (1990): Energy constraints on kinematic models of oblique faulting: Loma Prieta versus Parkfield-Coalinga.- Geophysical Research Letters, 17/9, 1453-1456. doi: 10.1029/GL017i009p01453

MIKES, T., BÁLDI-BEKE, M., KÁZMÉR, M., DUNKL, I., \& VON EYNATTEN, H. (2008): Calcareous nannofossil age constraints on Miocene flysch sedimentation in the Outer Dinarides (Slovenia, Croatia, Bosnia-Herzegovina and Montenegro).In: SIEGESMUND, S., FÜGENSCHUH. B. \& FROITZHEIM, N. (eds.): Tectonic Aspects of the Alpine-Dinaride-Carpathian System. Geol. Soc. London, Spec. Publ. 298, 335-363. doi: 10.1144/SP298.16

ORTNER, H., REITER, F. \& ACS, P. (2002): Easy handling of tectonic data: The programs TectonicVB for Mac and Tectonics FP forWindows ${ }^{\mathrm{TM}}$.- Computers and Geosciences, 28, 1193-1200.

PRELOGOVIĆ, E., BLAŠKOVIĆ, I., CVIJANOVIĆ, D., SKOKO, D. \& ALJINOVIĆ, B. (1981): Seizmotektonske značajke Vinodolskog područja (Seismotectonic characteristics of the Vinodol area).- Geol. vjesnik, 33, 75-93, Zagreb.

PRELOGOVIĆ, E., CVIJANOVIĆ, D., ALJINOVIĆ, B., KRANJEC, V., SKOKO, D., BLAŠKOVIĆ, I. \& ZAGORAC, Ž. (1982): Seizmotektonska aktivnost duž priobalnog dijela Jugoslavije (Seismotectonic activity along the coastal area of Yugoslavia).- Geol. vjesnik, 35, 195-207, Zagreb.

PRELOGOVIĆ, E., KUK, V., JAMIČIĆ, D., ALJINOVIĆ, B. \& MARIĆ, K. (1995): Seizmotektonska aktivnost Kvarnerskog područja (Seismotectonic activity of Kvarner area).- In: VLAHOVIĆ, I., VELIĆ, I. \& ŠPARICA, M. (eds.): 1. hrvatski geološki kongres (First Croatian Geological Congress), Zbornik radova 2 (Proceeding 2), 487-490, Zagreb.

SCHLANGER, S.O. \& JENKYNS, H.C. (1976): Cretaceous anoxic events: causes and consequences.- Geologie en Mijnbouw, 55/3-4, 179-184.

ŚRODOŃ, J., ANCZKIEWICZ, A.A., DUNKL, I., VLAHOVIĆ, I., VELIĆ, I., TOMLJENOVIĆ, B., KAWIAK, T., BANAŚ, M. \& VON EYNATTEN, H. (2018): Thermal history of the central part of the Karst Dinarides, Croatia: combined application of clay mineralogy and low-T thermochronology.- Tectonophysics, 744, 155-176. doi: 10.1016/j.tecto.2018.06.016

ŠIKIĆ, D., POLŠAK, A. \& MAGAŠ, N. (1969): Osnovna geološka karta SFRJ 1:100.000, list Crikvenica L 33-101 [Basic Geological Map of SFRY 1:100,000 Scale, Geology of the Crikvenica Sheet - in Croatian].- Institut za geološka istraživanja Zagreb (1958-1967), Savezni geološki zavod, Beograd.

ŠIKIĆ, D., PLENIČAR, M. \& ŠPARICA, M. (1972): Osnovna geološka karta SFRJ 1:100.000, list Ilirska Bistrica L 33-89 [Basic Geological Map of SFRY 1:100,000 Scale, Geology of the Ilirska Bistrica Sheet - in Croatian].- Institut za geološka istraživanja Zagreb (1958-1967), Savezni geološki zavod, Beograd.

ŠPANIČEK, J., ĆOSOVIĆ,V., MRINJEK, E. \& VLAHOVIĆ, I. (2017): Early Eocene evolution of carbonate depositional environments recorded in the Čikola Canyon (North Dalmatian Foreland Basin, Croatia).- Geologia Croatica, 70/1, 11-25. doi: $10.4154 / \mathrm{gc} .2017 .05$

ŠPARICA, M., KOCH, G., IBRAHIMPAŠIĆ, H., GALOVIĆ, I. \& BERGANT, S. (2005): Novi prinosi stratigrafiji paleogenskih klastično-karbonatnih naslaga jugoistočnog dijela Istre, Hrvatska (New contributions to stratigraphy of Paleogene clastic-carbonate deposits from southeastern Istria, Croatia).- In: VELIĆ, I., VLAHOVIĆ, I. \& BIONDIĆ, R. (eds.): 3. hrvatski geološki kongres (Third Croatian Geological Congress), Knjiga sažetaka (Abstracts Book), 147-148, Zagreb.

ŠUŠNJAR, M., BUKOVAC, J., NIKLER, L., CRNOLATAC, I., MILAN, A., ŠIKIĆ, D., GRIMANI, I., VULIĆ, Ž. \& BLAŠKOVIĆ, I. (1970): Osnovna geološka karta SFRJ 1:100.000, list Crikvenica L 33-102 [Basic Geological Map of SFRY 1:100,000 Scale, Geology of the Crikvenica Sheet - in Croatian].- Institut za geološka istraživanja Zagreb (1961-1969), Savezni geološki zavod, Beograd.

TAVANI, S., STORTI, F., BAUSÀ, J. \& MUÑOZ, A. (2012): Late thrusting extensional collapse at the mountain front of the northern Apennines (Italy).- Tectonics, 31. TC4019, 1-17. doi:10.1029/2011TC003059

TOMLJENOVIĆ, B., BALLING, P., MATOŠ, B., VLAHOVIĆ, I., SCHMID, S., USTASZEWSKI, K., BLAŽOK, L., POSARIĆ, D. \& ŠIROL, A. (2018): Structural architecture and tectonic evolution of the Velebit Mt. in the central part of the External Dinarides in Croatia.- In: NEUBAUER, F., BRENDEL, U. \& FRIEDL, G. (eds.): ABSTRACTS, Advances of Geology in southeast European mountain belts. XXI International Congress of the Carpathian Balkan Geological Association, September 10-13, 2018. Geologica Balcanica, p. 202.

TURNER, F.J. (1953): Nature and dynamic interpretation of deformation lamellae in calcite of three marbles.- American Journal of Science, 251, 276-298. doi: 10.2475/ajs.251.4.276

VAN UNEN, M., MATENCO, L., NADER, F.H., DARNAULT, R., MANDIĆ, O. \& DEMIR, V. (2019): Kinematic of foreland-vergent crustal accretion: inferences from the Dinarides evolution.- Tectonics, 38/1,49-76. doi:10.1029/2018TC005066

VELIĆ, I. \& VLAHOVIĆ, I. (1994): Foraminiferal assemblages in the Cenomanian of the Buzet-Savudrija area (Northwestern Istria, Croatia).- Geologia Croatica, 47/1, $25-43$.

VLAHOVIĆ, I., KORBAR, T., MORO, A., VELIĆ, I., SKELTON, P.W., FUČEK, L. \& TIŠLJAR, J. (2002): Latest Cenomanian to earliest Turonian platform drowning and turonian recovery of shallow-water platform deposition in southern Istria.Abstracts and Excursion Guidebook, Sixth International Congress on Rudists (Rovinj, Croatia), 123-127.

VLAHOVIĆ, I., TIŠLJAR, J., VELIĆ, I. \& MATIČEC, D. (2005): Evolution of the Adriatic Carbonate Platform: paleogeography, main events and depositional dynamics.- Palaeogeography, Palaeoclimatology, Palaeoecology, 220, 333-360. doi: 10.1016/j.palaeo.2005.01.011

VLAHOVIĆ, I., MANDIC, O., MRINJEK, E., BERGANT, S., ĆOSOVIĆ, V., DE LEEUW, A., ENOS, P., HRVATOVIĆ, H., MATIČEC, D., MIKŠA, G., NEMEC, W., PAVELIĆ, D., PENCIGER, V., VELIĆ I. \& VRANJKOVIĆ, A. (2012): Marine to continental depositional systems of Outer Dinarides foreland and intramontane basins (Eocene-Miocene, Croatia and Bosnia and Herzegovina).- Field Trip Guide, 29th IAS Meeting of Sedimentology, Schladming/Austria, Journal of Alpine Geology 54, 405-470.

ŽIBRET, L. \& VRABEC, M. (2016): Paleostress and kinematic evolution of the orogeny-parallel NW-SE striking faults in the NW External Dinarides of Slovenia unraveled by mesoscale fault-slip data analysis.- Geologia Croatica, 69/3, 295-305. doi: $10.4154 / \mathrm{gc} .2016 .30$ 